Louisiana State University

LSU Digital Commons

Faculty Publications

Department of Geology and Geophysics

$4-1-2010$

\title{
A dynamic physical model for soil temperature and water in Taylor Valley, Antarctica
}

H. W. Hunt

Colorado State University

A. G. Fountain

Portland State University

P. T. Doran

University of Illinois at Chicago

H. Basagic

Portland State University

Follow this and additional works at: https://digitalcommons.Isu.edu/geo_pubs

\section{Recommended Citation}

Hunt, H., Fountain, A., Doran, P., \& Basagic, H. (2010). A dynamic physical model for soil temperature and water in Taylor Valley, Antarctica. Antarctic Science, 22 (4), 419-434. https://doi.org/10.1017/ S0954102010000234

This Article is brought to you for free and open access by the Department of Geology and Geophysics at LSU Digital Commons. It has been accepted for inclusion in Faculty Publications by an authorized administrator of LSU Digital Commons. For more information, please contact ir@lsu.edu. 
Portland State University

PDXScholar

Geography Faculty Publications and

Presentations

Geography

$1-1-2010$

\title{
A Dynamic Physical Model for Soil Temperature and Water in Taylor Valley, Antarctica
}

\author{
H. W. Hunt \\ Colorado State University - Fort Collins \\ Andrew G. Fountain \\ Portland State University, andrew@pdx.edu \\ Peter T. Doran \\ University of Illinois at Chicago \\ Hassan J. Basagic \\ Portland State University, basagic@pdx.edu
}

Follow this and additional works at: https://pdxscholar.library.pdx.edu/geog_fac

Part of the Environmental Sciences Commons, Geology Commons, and the Glaciology Commons Let us know how access to this document benefits you.

\section{Citation Details}

H.W. Hunt, A.G. Fountain, P.T. Doran and H. Basagic (2010). A dynamic physical model for soil temperature and water in Taylor Valley, Antarctica. Antarctic Science, 22, pp 419-434 doi:10.1017/ S0954102010000234

This Article is brought to you for free and open access. It has been accepted for inclusion in Geography Faculty Publications and Presentations by an authorized administrator of PDXScholar. Please contact us if we can make this document more accessible: pdxscholar@pdx.edu. 


\title{
A dynamic physical model for soil temperature and water in Taylor Valley, Antarctica
}

\author{
H.W. HUNT ${ }^{1}$, A.G. FOUNTAIN ${ }^{2}$, P.T. DORAN ${ }^{3}$ and H. BASAGIC ${ }^{2}$ \\ ${ }^{I}$ Natural Resource Ecology Laboratory, Colorado State University, Fort Collins, CO 80523, USA \\ ${ }^{2}$ Department of Geology, Portland State University, Portland, OR 97201, USA \\ ${ }^{3}$ Earth and Environmental Sciences, University of Illinois at Chicago, Chicago, IL 60607, USA \\ billh@nrel.colostate.edu
}

\begin{abstract}
We developed a simulation model for terrestrial sites including sensible heat exchange between the atmosphere and ground surface, inter- and intra-layer heat conduction by rock and soil, and shortwave and longwave radiation. Water fluxes included snowmelt, freezing/thawing of soil water, soil capillary flow, and vapour flows among atmosphere, soil, and snow. The model accounted for $96-99 \%$ of variation in soil temperature data. No long-term temporal trends in soil temperature were apparent. Soil water vapour concentration in thawed surface soil in summer often was higher than in frozen deeper soils, leading to downward vapour fluxes. Katabatic winds caused a reversal of the usual winter pattern of upward vapour fluxes. The model exhibited a steady state depth distribution of soil water due to vapour flows and in the absence of capillary flows below the top $0.5 \mathrm{~cm}$ soil layer. Beginning with a completely saturated soil profile, soil water was lost rapidly, and within a few hundred years approached a steady state characterized by dry soil $(<0.5 \%$ gravimetric) down to one metre depth and saturated soil below that. In contrast, it took 42000 years to approach steady state beginning from a completely dry initial condition.
\end{abstract}

Received 11 August 2009, accepted 27 January 2010

Key words: capillary water, longwave radiation, matric potential, permafrost, solar radiation, water vapour

\section{Introduction}

The McMurdo Dry Valleys of Antarctica comprise the largest ice-free area on the Antarctic continent. They are important for the study of life in extreme environments (Priscu \& Christner 2004), as a physical analogue for Mars (McKay et al. 2005), and potentially as a source of information about ancient Earth climates (Sugden et al. 1995). Soil temperature and water are critical variables affecting soil biological activity in the Dry Valleys (Virginia \& Wall 1999). Buried ice has been found in the Dry Valleys but its age is controversial (Sugden et al. 1995, Hindmarsh et al. 1998, Ng et al. 2005). The buried ice could be important for reconstructing past climates. The rate of vapour transport through overlying till provides one approach for estimating ice age, but published models for soil temperature and water in the Dry Valleys (e.g. Hindmarsh et al. 1998, McKay et al. 1998, Schorghofer 2005, Kowalewski et al. 2006, Hagedorn et al. 2007) are deficient because they do not deal mechanistically with exchanges between soil and atmosphere, and do not treat soil water dynamically.

Doran et al. (2002a, 2002b) analysed meteorological records from the McMurdo Dry Valleys for the period 1986-2000 and found significant declines in summer air temperature, cloudiness and wind speed. The first trend would be expected to decrease summer soil temperature, and the latter two trends to increase it. Thus it is not obvious whether trends in summer soil temperature will follow those in air temperature.
The objective of our research was to construct a mechanistic model of soil temperature and water, specific to the McMurdo Dry Valleys. The model was intended to be applicable for examining abiotic controls of soil biological activity, for predicting soil temperature and water at sites with only standard meteorological observations, and for estimating the rates of water fluxes for various scenarios of soil water content and climate. These objectives required a model that mechanistically treats the processes of heat and water fluxes within soil and between soil and atmosphere.

\section{Literature}

Sugden et al. (1995) estimated the age of buried ice in Beacon Valley, an Antarctic Dry Valley, at 8.1 million years based on argon dating of overlying ash deposits. If the buried ice is as old as the ash, this provides important evidence about the ancient Antarctic climate (Sugden et al. 1995, Marchant et al. 2002). The preservation of ancient ice would imply a low rate of sublimation loss. Estimates of sublimation rates based on the depth distribution of cosmogenic noble gases in till overlying old ice are as low as $c .0 .005 \mathrm{~mm} \mathrm{yr}^{-1}$ (Schäfer et al. 2000, Marchant et al. 2002, Ng et al. 2005). Physical models of vapour transport through till under current climate conditions (McKay et al. 1998, Schorghofer 2005, Kowalewski et al. 2006, Hagedorn et al. 2007) have yielded higher sublimation rates $\left(0.1-0.5 \mathrm{~mm} \mathrm{yr}^{-1}\right)$ assumed to be incompatible with the preservation of ancient buried 
Table I. Site characteristics of meteorological stations (Doran et al. 2002a), and datasets used for model tuning or validation.

\begin{tabular}{lccc}
\hline & & Site & Hoare \\
\hline Station elevation, m a.s.1 & Bonney & 72 & Fryxell \\
Distance from coast, km & 60 & 15 & 20 \\
Average mean annual air temperature, ${ }^{\circ} \mathrm{C}$ & 25 & -17.7 & \\
Average mean annual solar flux, $\mathrm{W} \mathrm{m}^{-2}$ & -17.9 & 84 & \\
Dataset & 94 & Starting date (number of days) & 100 \\
1 & & $21.10 .2002(791)$ & $30.11 .1994(1967)$ \\
2 & $17.11 .2000(959)$ & $18.12 .1993(336)$ & $23.07 .2000(338)$ \\
3 & $05.12 .1994(237)$ & $28.12 .1994(336)$ & $28.11 .2001(1525)$ \\
4 & $09.11 .1995(973)$ & $20.12 .2004(375)$ & - \\
5 & $12.11 .1998(716)$ & - & - \\
\hline
\end{tabular}

ice. However, several of these models treat only frozen soil or deal only with summer conditions. None of the models treat sensible heat exchange and vapour exchange between the soil surface and the atmosphere. Several of the models assume a linear gradient of water vapour pressure through the soil from the surface down to the buried ice, and thus implicitly assume that capillary water is in equilibrium with an assumed vapour pressure gradient. Schorghofer \& Aharonson (2005), examining ice distribution on Mars, constructed a model similar to that of Kowalewski et al. (2006), but which included equations for soil water content ("adsorbed water"). They concluded that the inclusion of adsorbed water in their model was unimportant for estimates of the relationship between the atmospheric concentration of water vapour and the depth and amount of buried ice, as long as the adsorbed water was in local equilibrium with an assumed linear gradient of water vapour pressure in the soil profile. Several authors (Hindmarsh et al. 1998, Schorghofer 2005) have acknowledged that it is necessary to treat the relationship between soil water and vapour pressure to estimate ice sublimation rates, but none have examined seasonal variation of capillary water under the influence of atmospheric driving variables, or the disequilibrium in vapour pressure gradient attending periodic water input to the soil.

\section{Materials and methods}

We adapted models to three terrestrial sites (Table I), each free of permanent ice and within a few metres of ice-covered
Lakes Bonney, Hoare or Fryxell in Taylor Valley, Antarctica (Priscu 1999, and other articles in Bioscience Volume 49, No. 12). Doran et al. (1995) described meteorological instrumentation at the sites, and data can be found online at the McMurdo Dry Valleys Long Term Ecological Research project site (http://mcmlter.org/queries/met/met_home.jsp, accessed October 2009). Many of these data, up to the year 2000, were analysed by Doran et al. (2002a). For present purposes, the data were divided into sets used for model calibration and for validation tests (Table I).

\section{Simulation model}

The energy model incorporates concepts of energy fluxes at a bare soil surface, based on the model of Matthias (1990). Components of the energy budget include net radiation $\left(R_{n}\right)$, sensible heat $(H)$, latent heat (LE) and soil heat conduction $(\mathrm{G})$. All these components of the surface energy balance are functions of surface temperature. In the model of Matthias (1990) and many other energy balance models, the value of a theoretical surface temperature $\left(\mathrm{T}_{\mathrm{sfc}}\right)$ is estimated iteratively to achieve a balance among the processes adding and removing energy from the surface. That is, a constant $T_{\text {sfc }}$ is estimated so that:

$$
\mathrm{R}_{\mathrm{n}}-\mathrm{H}-\mathrm{LE}-\mathrm{G}=0
$$

The rates of processes at the equilibrium $\mathrm{T}_{\mathrm{sfc}}$ are then assumed to apply over the time interval for which the driving variables are averaged, typically 24 hours. We took a slightly different approach, for reasons explained below.

Table II. Site specific parameters of the simulation model.

\begin{tabular}{|c|c|c|c|c|c|c|}
\hline \multicolumn{3}{|l|}{ Parameter } & \multicolumn{4}{|c|}{ Site } \\
\hline Definition or process & Symbol & Location & Bonney & Hoare & Fryxell & Yuma $^{1}$ \\
\hline Soil emissivity multiplier (non-dimensional) & $\mathrm{m}_{1}$ & Eq. (4) & 1.12 & 0.85 & 0.80 & 0.98 \\
\hline Rock emissivity multiplier (non-dimensional) & $\mathrm{m}_{1}$ & Eq. (4) & 1.24 & 0.80 & 0.71 & - \\
\hline Rock/soil roughness length $(\mathrm{m})$ & - & text & 0.00104 & 0.00189 & 0.0087 & 0.0065 \\
\hline Rock/soil albedo (fraction) & - & text & 0.066 & 0.142 & 0.130 & 0.26 \\
\hline Rock thermal conductivity $\left(\mathrm{W} \mathrm{m}^{-1} \mathrm{~K}^{-1}\right)$ & - & text & 3.5 & 1.5 & 4.4 & - \\
\hline Snow emissivity (fraction) & $\varepsilon_{\mathrm{w}}$ & text & 0.977 & 0.952 & 0.862 & - \\
\hline Snow cover (fraction) & - & text & 0.102 & 0.167 & 0.408 & - \\
\hline
\end{tabular}

${ }^{1}$ Fallow field at Yuma, Arizona, USA (Matthias 1990). 


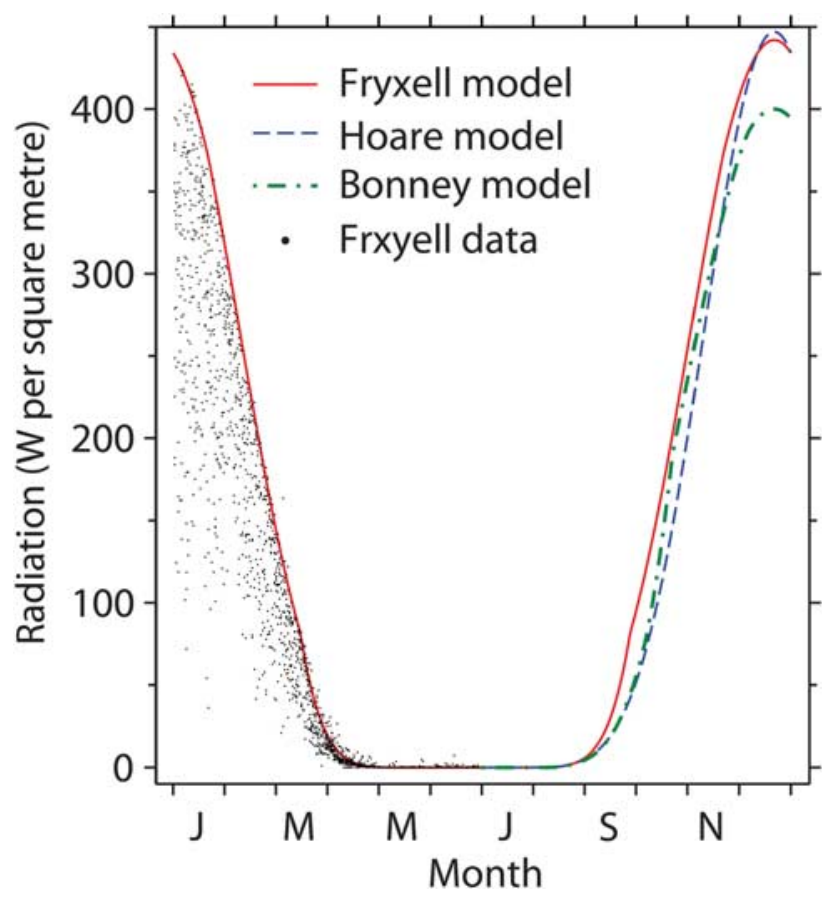

Fig. 1. Average daily incoming shortwave radiation at Taylor Valley sites. Observed radiation at the Fryxell site is shown for the first six months. The lines are for modelled maximal radiation.

Because the McMurdo Dry Valleys are rocky, the surface layer is divided into rock and soil fractions with different thermal properties. Furthermore, a fraction of the surface may be covered with snow. Thus our model includes three different surface temperatures: for rock, soil, and snow. To calculate sensible heat exchange with the atmosphere as a function of surface temperature, we used the area-weighted average temperature of rock, soil and snow. In an early version of the model, we tried the above approach of Matthias for estimating equilibrium $\mathrm{T}_{\mathrm{sfc}}$, but found that the iterative procedure solving simultaneously for three surface temperatures was complicated, computationally inefficient and not reliably stable. Therefore we replaced the concept of a boundary surface temperature with that of the temperature of a thin $(0.5 \mathrm{~cm})$ surface layer. Rather than solving for instantaneous steady state values of the surface layer temperatures $\left(\operatorname{Tr}_{1}, \mathrm{Ts}_{1}\right.$, and $\mathrm{Tw}_{1}$ for top layers of rock, soil, and snow, respectively), the energy fluxes were allowed to operate over short (much less than one day) time intervals, and temperatures were updated as a function of surface layer heat contents and heat capacities. Using this approach of a thin surface layer, surface temperatures approached steady state values within a fraction of a day, using driving variables that were constant over a day. The model was dynamically stable with this solution technique.

Net radiation in the model is the sum of incoming shortwave, reflected shortwave, incoming longwave, and emitted longwave radiation, each calculated separately for rock, soil, and snow surfaces. Incoming shortwave radiation $\left(\mathrm{W} \mathrm{m}^{-2}\right)$ observed at Taylor Valley sites is a driving variable. Reflected shortwave radiation is predicted from the albedos of rock, soil (Table II) and snow. Snow albedo is assumed constant (0.90) at all sites. Incoming longwave radiation $\left(\mathrm{R}_{1}\right)$ is predicted from air temperature $\mathrm{T}_{\mathrm{a}}(\mathrm{K})$, following Matthias (eq. (8), 1990):

$$
\mathrm{R}_{1}=\varepsilon_{\mathrm{c}} \sigma \mathrm{T}_{\mathrm{a}}^{4},
$$

where $\varepsilon_{\mathrm{c}}$ is atmospheric emissivity and $\sigma$ is the StefanBoltzmann constant $\left(5.67 \times 10^{-8} \mathrm{~W} \mathrm{~m}^{-2} \mathrm{~K}^{-4}\right)$. Atmospheric emissivity $\varepsilon_{\mathrm{c}}$ is calculated as a function of $\mathrm{T}_{\mathrm{a}}$ and cloud cover (eqs (9) \& (10) in Matthias 1990). Cloud cover $c_{f}$ is estimated from observed incoming shortwave radiation $R_{s}$ and estimated maximal incoming shortwave radiation $R_{\mathrm{sm}}$.

$$
c_{\mathrm{f}}=1-\mathrm{R}_{\mathrm{s}} / \mathrm{R}_{\mathrm{sm}}
$$

Maximal radiation $\mathrm{R}_{\mathrm{sm}}$ as a function of season was estimated by fitting empirical curves to maximal radiation observed over an approximately ten year period (Fig. 1). The curves vary among sites because of shading from mountains in the Asgard Range (Dana et al. 1998). These estimates of cloud cover might also be affected by unobserved variations in atmospheric transmissivity.

Longwave radiation emitted from the ground surface is predicted from Eq. (2), substituting surface layer temperatures $\mathrm{Tr}_{1}, \mathrm{Ts}_{1}$, or $\mathrm{Tw}_{1}$ for $\mathrm{T}_{\mathrm{a}}$, and using the corresponding emissivities of rock, soil and snow in place of $\varepsilon_{\mathrm{c}}$. Snow emissivity $\varepsilon_{\mathrm{w}}$ was estimated to maximize the fit to data. The value of $\varepsilon_{\mathrm{w}}$ varies among sites (Table II), but stays within the range for snow and ice given by Hori et al. (2006). We developed an equation for soil emmisivity $\varepsilon_{\mathrm{s}}$ as a function of surface temperature $\mathrm{TCs}_{1}\left({ }^{\circ} \mathrm{C}\right)$, applicable between -40 and $15^{\circ} \mathrm{C}$, based on data of Wan (http://www.icess.ucsb.edu/ modis/EMIS/images/goleta2.prn, accessed November 2006) for beach sand:

$$
\varepsilon_{\mathrm{s}}=\mathrm{m}_{1}\left(0.941-0.00214 \mathrm{TCs}_{1}-0.0000285 \mathrm{TCs}_{1}^{2}\right),
$$

where $\mathrm{m}_{1}$ is a site-specific multiplier (Table II), and $\varepsilon_{\mathrm{s}}$ is constrained to be $<1.0$. Multiplier $\mathrm{m}_{1}$ is 1.0 for the data of Wan (as above). Rock emissivity $\varepsilon_{\mathrm{r}}$ is assumed to depend on temperature according to Eq. (4) with site-specific multipliers $\mathrm{m}_{1}$ as given in Table II.

Sensible heat exchange between the atmosphere and surface layer is formulated as in Matthias (eqs (12)-(17), 1990), except that his eq. (15) for the heat exchange coefficient under unstable conditions, $\mathrm{C}_{\mathrm{hu}}$, is replaced by the following corrected equation (Matthias, personal communication 1 November 2006, see also Mahrt \& Ek 1984):

$$
\mathrm{C}_{\mathrm{hu}}=\mathrm{C}_{\mathrm{hn}}\left\{1-\left[15 \mathrm{R}_{\mathrm{i}} /\left(1+\mathrm{C}_{\mathrm{o}}\left(-\mathrm{R}_{\mathrm{i}}\right)^{0.5}\right)\right]\right\} \text {, }
$$

where $C_{h n}$ is the coefficient under neutral conditions, and $C_{o}$ is a function of instrument height. The bulk Richardson number $R_{i}$ is calculated using eq. (13) from Matthias (1990), replacing 
Table III. Ground layer properties in the simulation model.

\begin{tabular}{lccc}
\hline $\begin{array}{l}\text { Depth } \\
(\mathrm{cm})\end{array}$ & Rock fraction & $\begin{array}{c}\text { Rock diameter } \\
(\mathrm{cm})\end{array}$ & $\begin{array}{c}\text { Soil fraction bulk density } \\
\left(\mathrm{g} \mathrm{cm}^{-3}\right)\end{array}$ \\
\hline $0-0.5$ & 0.45 & 10 & 1.5 \\
$0.5-3$ & 0.45 & 10 & 1.5 \\
$3-7$ & 0.7 & 12 & 1.6 \\
$7-13$ & 0.7 & 14 & 1.6 \\
$13-22$ & 0.8 & 16 & 1.7 \\
$22-35$ & 0.8 & 18 & 1.7 \\
$35-55$ & 0.85 & 20 & 1.7 \\
$55-100$ & 0.9 & 22 & 1.7 \\
$100-150$ & 0.9 & 24 & 1.7 \\
$150-250$ & 0.9 & 26 & 1.7 \\
$250-350$ & 0.9 & 26 & 1.7 \\
$350-550$ & 0.9 & 26 & 1.7 \\
$550-1000$ & 0.9 & 26 & 1.7 \\
\hline
\end{tabular}

his values of surface roughness and surface temperature with area-weighted averages of the rock, soil and snow surfaces (Table II). The critical value of $\mathrm{R}_{\mathrm{i}}$, above which laminar flow ensues, is 0.2 , in the middle of the range of literature values given by Matthias (1990).

Latent heat flux in the surface layer is predicted from freezing/thawing of soil water and from water vapour exchange with the atmosphere and with the second soil layer. Water vapour exchange between the surface soil layer and atmosphere (instrument height $=3 \mathrm{~m}$ ) is predicted from the humidity gradient and wind speed using an atmospheric transport equation (eq. (5) in Kondo et al. 1990). The bulk coefficient for water vapour exchange is assumed the same as that for heat exchange as calculated according to Matthias (1990, see above). Saturation vapour pressure in the atmosphere as an empirical function of temperature is calculated using eq. (6) in Murray (1967). Humidity at instrument height is calculated from saturation humidity and relative humidity. In soil air, water vapour pressure is assumed to be in local equilibrium with ice or capillary water because of the large surface areas and short diffusion distances involved. In frozen soil, soil air humidity is the same as that over ice at the predicted soil temperature. In unfrozen soil, vapour pressure is calculated from soil water matric potential (assuming zero osmotic potential) using the Kelvin equation. Matric potential is estimated as a function of soil texture, bulk density and volumetric soil water using a water-release equation formulated for sandy soils typical of the McMurdo Dry Valleys (eq. (4) in Hunt et al. 2007), assuming $4.4 \%$ clay, $90.5 \%$ sand, and an average sand particle diameter of $0.28 \mathrm{~mm}$. Soil bulk density is assumed to increase with depth (Table III). Water vapour exchange and latent heat flux in the top layer of snow is calculated using the same equations as for soil, except that the relative humidity of air in the snow is assumed to be $100 \%$. Vapour exchange between the atmosphere and wetted rock surfaces is not considered.

Snow cover was estimated as a function of albedo, calculated from incoming and reflected shortwave radiation.
There was a regular seasonal pattern at all three sites (except in midwinter when low light precluded calculation), with very high snow cover in spring and autumn and low cover in summer. However, the radiation sensors are at $3 \mathrm{~m}$ height, and a fraction of reflected shortwave radiation appears attributable to nearby snowfields, glaciers and ice-covered lakes (Dana et al. 1998), in addition to local snow at the meteorological stations. We used regression analysis to statistically remove the regular variation in reflected shortwave radiation related to seasonal changes in sun angle in relation to the positions of glaciers and lakes. The residual (local snow cover) was much more variable than the uncorrected estimates, and was generally greater in spring and autumn, and lower in summer, which agrees with field observations. However, using constant snow cover in the model gave a better fit to temperature observations at two of the three sites (Hoare and Fryxell) than using variable snow cover (either corrected or uncorrected for reflection from lakes and glaciers). This suggests that: 1) reflection at $3 \mathrm{~m}$ height assesses snow cover over a much larger area than that (presumably $<1 \mathrm{~m}^{2}$ ) influencing the soil temperature sensors, 2) reflectivity of glaciers and lakes varies importantly between years, or 3) snow depth in addition to snow cover is necessary to predict soil temperature. We compared three snow indicators at the Bonney site based on direct snow depth measurements, observed albedo, and the departure between observed emitted longwave radiation and that predicted from observed soil surface temperatures. There was no useful correspondence among the three indicators. Thus for predicting temperatures, we assigned a constant snow cover (Table II) equal to the annual average corrected snow cover at each site. This assumption is relaxed for some model exercises (below). Seasonal minimum observations of albedo were used to constrain estimates of rock and soil albedo in the model (Table II).

The ground, composed of soil and rocks, is divided into discrete layers to a depth of $10 \mathrm{~m}$ (Table III). The rock fraction increases with depth in accordance with information from near the Hoare site (Campbell 2003). Heat capacity of the rocks is set to $1.32 \mathrm{Jg}^{-1}{ }^{\circ} \mathrm{C}^{-1}$, within the range for non-porous rocks. Heat flux between adjacent layers is calculated separately for the rock and soil fractions, because of the large differences in thermal conductivities of rock and dry soil. Heat flux between layers occurs only from rock to rock or from soil to soil, on the assumption that rock-soil interfaces do not coincide exactly with interfaces between layers. For both soil and rock, interlayer flux is calculated according to Matthias (eq. (24), 1990), except that the flux is also proportional to the average fraction of soil (or rock) for the two layers. The effect of temperature TC (centigrade) on rock thermal conductivity is based on eq. (3a) in Clauser \& Huenges (1995):

$$
\lambda_{\mathrm{T}}=[\mathrm{A}+\mathrm{B} /(350+\mathrm{TC})] / 3.29,
$$

where $\lambda_{\mathrm{T}}$ is a temperature multiplier, normalized to equal 1.0 at $25^{\circ} \mathrm{C}$, for site-specific values of rock thermal conductivity 
(Table II), A $\left(0.985 \mathrm{~J}^{\circ} \mathrm{K}^{-1} \mathrm{~m}^{-1} \mathrm{sec}^{-1}\right)$ and B (863, complex units) are constants estimated to achieve a fit to data in Clauser \& Huenges (1995, fig. 2c) for plutonic rocks poor in feldspar (which include granite), and 3.29 is estimated thermal conductivity at $25^{\circ} \mathrm{C}$. Soil thermal conductivity is predicted as a function of temperature, gravimetric soil water (liquid and ice) and bulk density. If gravimetric water is $>1 \%$, equations developed by Kersten (1949) for frozen and unfrozen sands and gravels are used. For drier soils, a constant value $\left(0.24 \mathrm{~J}^{\circ} \mathrm{K}^{-1} \mathrm{~m}^{-1} \mathrm{sec}^{-1}\right)$ for quartz sand is used (fig. 2, Buchan 1991). Intra-layer heat conduction between rock and soil is calculated using similar equations as for interlayer flows. The conducting area (surface area of rocks) and the average distance between the centres of rocks and pockets of soil are calculated as a function of layer thickness, fraction of rocks and soil by volume, and by assuming a simple geometry of regularly spaced uniform spherical rocks. The equations require a single new parameter, rock diameter (Table III), assumed invariable across sites. Thermal conductivity for intra-layer heat flux is taken as the weighted average of rock and soil conductivity.

The freezing point of capillary soil water is calculated as a function of soil water potential according to Buchan (eq. (34), 1991), assuming zero osmotic potential and zero ice pressure. If the layer temperature exceeds the freezing temperature, ice melts at a rate proportional to the mass of ice, the difference between freezing and layer temperatures, and to an empirical rate constant $\left(10 \mathrm{day}^{-1}{ }^{\circ} \mathrm{C}^{-1}\right)$. Varying the rate constant had little effect on temperature dynamics, because freezing and melting are ultimately controlled by heat transfers between layers, which are modelled mechanistically. Latent heat flux is proportional to water frozen or thawed. Freeze/thaw flows are suspended in dry soil (volumetric water $<0.5 \%$ ) to speed model solution.

The movement of soil water vapour from layer $i$ to layer $\mathrm{j}, \mathrm{Q}_{\mathrm{ij}}^{\mathrm{v}}\left(\mathrm{m}^{3} \mathrm{sec}^{-1}\right)$, is calculated from the humidity gradient assuming Fickian diffusion:

$$
\mathrm{Q}_{\mathrm{ij}}^{\mathrm{v}}=\mathrm{D} \rho \mathrm{PA}\left(\mathrm{v}_{\mathrm{i}}-\mathrm{v}_{\mathrm{j}}\right) / \mathrm{L},
$$

where $\mathrm{D}$ is the diffusivity of water vapour, $\rho$ is air density, $\mathrm{P}$ is air-filled soil porosity, $\mathrm{A}\left(\mathrm{m}^{2}\right)$ is the cross-sectional area of soil between layers, $v_{i}$ and $v_{j}$ are the specific humidity of air in layers $\mathrm{i}$ and j, and L (m) is the distance between midpoints of the two layers. Tortuosity is not considered for these sandy soils. Diffusivity D $\left(\mathrm{m}^{2} \mathrm{sec}^{-1}\right)$ as a function of temperature is predicted according to Kondo et al. (eq. (6), 1990). Air density $\rho\left(\mathrm{kg} \mathrm{m}^{-3}\right)$ is calculated as a function of temperature (Matthias 1990). Air-filled porosity $\mathrm{P}$ is total porosity minus the volume of ice and water. Total soil porosity is calculated from bulk density and the specific gravity of solid constituents (Hunt et al. 2007). Specific humidity v is calculated as explained above for latent heat flux in the surface layer. Soil water vapour is not a state variable in the model, because its mass will be orders of magnitude less than water or ice. Thus vapour fluxes between layers are handled as exchanges among the state variables for water and ice. For vapour flows involving layers with mixtures of water and ice, the flow is assigned to the predominant phase, which determines the appropriate latent heat fluxes. The balance among ice, capillary water and vapour pressure is then re-established via the freeze-thaw process described above, including latent heat fluxes.

Capillary water flow $\mathrm{Q}_{\mathrm{ij}}^{1}\left(\mathrm{~m}^{3} \mathrm{sec}^{-1}\right)$ from soil layer i to layer j is calculated using Darcy's law (Fetter 1994):

$$
\mathrm{Q}_{\mathrm{ij}}^{1}=\mathrm{KA}\left(\mathrm{h}_{\mathrm{j}}-\mathrm{h}_{\mathrm{i}}\right) / \mathrm{L},
$$

where $\mathrm{K}\left(\mathrm{m} \mathrm{sec}^{-1}\right)$ is hydraulic conductivity (defined below), $h_{i}$ and $h_{j}(m)$ are the hydraulic heads in layers $\mathrm{i}$ and $\mathrm{j}, \mathrm{A}$ is cross sectional area and $\mathrm{L}$ is distance between layers. Hydraulic head $\mathrm{h}$ is the sum of elevational head $(\mathrm{m})$ and water potential head $h_{p}(m)$, which is calculated from water potential $\psi(\mathrm{kPa})$ (Fetter 1994):

$$
\mathrm{h}_{\mathrm{p}}=-1000 \psi /(\mathrm{g} \mathrm{sg}) \text {, }
$$

where 1000 converts $\mathrm{kPa}$ to $\mathrm{Pa}\left(\mathrm{Pa}=\mathrm{kg} \mathrm{m}^{-1} \mathrm{sec}^{-2}\right)$, $\mathrm{g}$ is the acceleration of gravity $\left(9.8 \mathrm{~m} \mathrm{~s}^{-2}\right)$ and $\mathrm{sg}$ is the specific gravity of water, assumed equal to $1020 \mathrm{~kg} \mathrm{~m}^{-3}$. Saturated hydraulic conductivity $\mathrm{K}_{\mathrm{s}}\left(\mathrm{m} \mathrm{s}^{-1}\right)$ is calculated according to eq. (5) in Rawls et al. (1998):

$$
\mathrm{K}_{\mathrm{s}}=\mathrm{C} \theta_{\mathrm{e}}^{\mathrm{D}},
$$

where constants $\mathrm{C}\left(0.000536 \mathrm{~m} \mathrm{~s}^{-1}\right)$ and $\mathrm{D}$ (2.3, nondimensional) have values appropriate to sand textured soils, and $\theta_{\mathrm{e}}$ is "effective porosity", defined as total porosity minus volumetric water content at $-33 \mathrm{kPa}$ water potential (Rawls et al. 1998). Effective porosity is calculated using the waterrelease equation discussed above (Hunt et al. 2007). Unsaturated hydraulic conductivity $\mathrm{K}$ is predicted from $\mathrm{K}_{\mathrm{s}}$ and matric potential $\psi(\mathrm{kPa})$ using an empirical equation (eq. (1) in Jaynes \& Tyler 1984):

$$
\mathrm{K}=\mathrm{K}_{\mathrm{s}} \exp \left[\beta(-\psi)^{1 / 2}\right],
$$

where constant $\beta$ has a value (2.8, complex units) estimated for a sand textured soil (site 10, Jaynes \& Tyler 1984), and operator $\exp (\mathrm{x})$ denotes $\mathrm{e}^{\mathrm{x}}$, with $\mathrm{e}$ the base of natural logarithms. To evaluate Eq. (8), hydraulic conductivity is taken as the average $\mathrm{K}$ in layers $\mathrm{i}$ and $\mathrm{j}$, and area $\mathrm{A}$ is 1.0 minus the average rock fraction in the two layers.

The rates of radiation, heat and water fluxes described above are collected into a set of difference equations for the rates of change of state variables: heat, water and ice in the soil and rock fractions of each of 13 soil layers. The equations are solved using a variable time step chosen to limit the rate of change of the most rapidly changing state variable (typically water in the surface layer) to less than $1 \%$ per time step, which gives a satisfactory compromise between execution time and accuracy of integration. At the end of each simulated day the final equilibrated values of 
simulated longwave radiation and soil temperatures are compared with the observed daily mean values.

Some model parameters (Table II) were estimated, using enhanced SIMPLEX optimization (Hunt et al. 2003), to give the best fit of the model to observed temperature, radiation and degree days. Degree days is the sum of average daily temperature $\left({ }^{\circ} \mathrm{C}\right)$ for days with temperature above $0^{\circ} \mathrm{C}$. Moorhead et al. (2002) found that degree days correlated strongly with nematode population growth predicted by a population model. The fit of our model to degree days was included to improve the prediction of summer temperatures critical to biological activity. The objective function $\mathrm{Q}$ minimized by the optimization procedure is:

$$
\mathrm{Q}=\mid(\mathrm{DDm}-\mathrm{DDd}) / \mathrm{DDd}) \mid+\Sigma\left(1-\mathrm{R}_{\mathrm{i}}^{2}\right),
$$

where DDm is predicted degree days in the third soil layer $(3-7 \mathrm{~cm})$, DDd is observed degree days at $5 \mathrm{~cm}$ soil depth, and $\mathrm{R}_{\mathrm{i}}^{2}$ is the coefficient of determination for data type i. For the Bonney site, data included incoming and emitted longwave radiation and soil temperatures at 0,5 and $10 \mathrm{~cm}$. For the other two sites (Hoare and Fryxell), data included only 5 and $10 \mathrm{~cm}$ temperatures.

For each site, data were divided into calibration and validation sets. Site specific parameters (Table II) were estimated using the calibration sets only. Fits to the validation sets tested the predictive power of the model. We attempted to minimize the number of parameters with different values for the three sites. Initial values of soil water and temperature in each layer were arrived at by repeatedly running the model with the calibration set, taking the final values of temperature and soil water as the initial values for the next run, and repeating this process until the final values were close to the initial values. Thus we assumed that the initial values of temperature and water in the tuning runs were not grossly out of equilibrium with the subsequent driving variables. However, these initial values differed from a true model steady state which was found by a different technique described below. Initial values of temperature and water in the validation runs were set equal to the corresponding values for the same day and month in the calibration run.

\section{Statistical models}

Regression models were constructed to predict daily average soil temperatures as a function of driving variables. Linear regression models were formulated using BMDP program 1R (Dixon 1985). Variables with tolerance of less than 0.01 were omitted from the equation (coefficients of zero). Regression models were formulated using the same driving variables and distinguishing the same calibration and validation datasets as used for the simulation model. For examining long term trends, we calculated averages for seasonal periods within which there were no missing daily averages over multiple years, to avoid confounding between season and year of measurement. For example, at the Bonney site there were

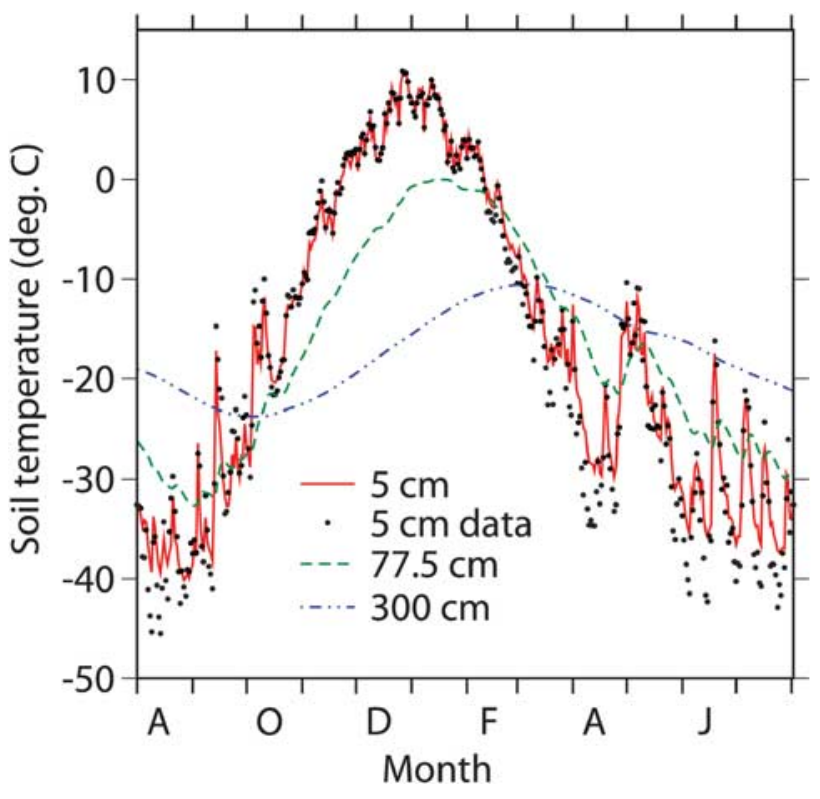

Fig. 2. Simulated temperatures and observed $5 \mathrm{~cm}$ depth temperatures at the Bonney site in 2001-02.

uninterrupted series of data between 17 November and 29 July for eight periods between 1994 and 2005. Within each period, separate averages were calculated for two seasons, demarcated by the average date when average daily temperature at $10 \mathrm{~cm}$ depth first dropped below $-10^{\circ} \mathrm{C}$. At the Bonney site, this date varied over eight years between

Table IV. Fit (square root of mean squared error) of simulation models to data.

\begin{tabular}{|c|c|c|c|c|}
\hline \multirow[t]{2}{*}{ Variable } & \multirow[t]{2}{*}{ Dataset $^{1}$} & \multicolumn{3}{|c|}{ Site } \\
\hline & & Bonney & Hoare & Fryxell \\
\hline \multirow[t]{5}{*}{ Temperature, $0 \mathrm{~cm}\left({ }^{\circ} \mathrm{C}\right)$} & 1 & $2.2(\mathrm{t})$ & 2.6 & 2.7 \\
\hline & 2 & 2.4 & 2.9 & 2.7 \\
\hline & 3 & 2.1 & 2.7 & 2.3 \\
\hline & 4 & 2.1 & 2.6 & \\
\hline & 5 & 1.85 & & \\
\hline \multirow[t]{5}{*}{ Temperature, $5 \mathrm{~cm}\left({ }^{\circ} \mathrm{C}\right)$} & 1 & $2.1(\mathrm{t})$ & $2.5(\mathrm{t})$ & $2.4(\mathrm{t})$ \\
\hline & 2 & 2.4 & 2.6 & 2.4 \\
\hline & 3 & 2.2 & 2.5 & 2.1 \\
\hline & 4 & 2.4 & & \\
\hline & 5 & 2.1 & & \\
\hline \multirow[t]{5}{*}{ Temperature, $10 \mathrm{~cm}\left({ }^{\circ} \mathrm{C}\right)$} & 1 & $1.63(\mathrm{t})$ & $2.0(\mathrm{t})$ & $1.81(\mathrm{t})$ \\
\hline & 2 & 2.0 & 2.8 & 1.68 \\
\hline & 3 & 1.59 & 2.2 & 1.56 \\
\hline & 4 & 1.73 & 2.2 & \\
\hline & 5 & 1.44 & & \\
\hline \multirow[t]{3}{*}{ Outgoing long-wave radiation $\left(\mathrm{W} \mathrm{m}^{-2}\right)$} & 1 & $9.4(t)$ & & \\
\hline & 4 & 20 & & \\
\hline & 5 & 11.8 & & \\
\hline \multirow[t]{3}{*}{ Incoming long-waveradiation $\left(\mathrm{W} \mathrm{m}^{-2}\right)$} & 1 & $26(t)$ & & \\
\hline & 4 & 38 & & \\
\hline & 5 & 26 & & \\
\hline
\end{tabular}

${ }^{1}$ datasets defined in Table I.

$\mathrm{t}=$ tuning Dataset; otherwise a validation set. 
Table V. Observed and simulated degree days (the sum of daily average temperatures above $0^{\circ} \mathrm{C}$ ) at $5 \mathrm{~cm}$ depth. Only summer seasons with complete records are included.

\begin{tabular}{|c|c|c|c|c|c|c|}
\hline \multirow[t]{3}{*}{ Season } & \multicolumn{6}{|c|}{ Site } \\
\hline & \multicolumn{2}{|c|}{ Bonney } & \multicolumn{2}{|c|}{ Hoare } & \multicolumn{2}{|c|}{ Fryxell } \\
\hline & Observed & Predicted & Observed & Predicted & Observed & Predicted \\
\hline $1986-87$ & & & & 406 & & \\
\hline 1989-90 & & & & 296 & & \\
\hline 1990-91 & & & & 356 & & \\
\hline 1991-92 & & & & 225 & & \\
\hline 1992-93 & & & & 256 & & \\
\hline 1993-94 & & 236 & & & & \\
\hline 1994-95 & 259 & 246 & & & & \\
\hline 1995-96 & 382 & 387 & & & 142 & 119 \\
\hline 1996-97 & & & & 318 & 114 & 105 \\
\hline 1997-98 & & & & 239 & 74 & 70 \\
\hline 1998-99 & 280 & 284 & & 315 & 97 & 107 \\
\hline 1999-00 & 277 & 28 & & 293 & 48 & 75 \\
\hline 2000-01 & 262 & 26 & & 219 & 22 & 31 \\
\hline 2001-02 & 399 & 411 & & 399 & 150 & 142 \\
\hline 2002-03 & & & & & 60 & 40 \\
\hline 2003-04 & & & 323 & 312 & 103 & 74 \\
\hline 2004-05 & 357 & 342 & 337 & 330 & 128 & 76 \\
\hline
\end{tabular}

23 February and 3 March. Independent variables were the mean Julian dates for the two seasons.

\section{Results}

Models

Table II gives site-specific values for seven parameters found to strongly influence the fit of the simulation model to data and to require different values at different sites. Parameter values used in the original model formulation of Matthias (1990) are included for comparison, and these generally fall within the range for the McMurdo Dry Valley sites, except for rock/soil albedo which is highest at the agricultural site. Our values for albedo of rocks and soil (0.066-0.142) are within the range of 0.061-0.26 given by Campbell et al. (1997a) for several Dry Valley locations.
Table VII. Residual error (square root of mean squared error, ${ }^{\circ} \mathrm{C}$ ) for within site comparisons of simulation and regression models of soil temperature. The model type by depth interaction is significant at $P<0.0001$.

\begin{tabular}{lcc}
\hline Depth $(\mathrm{cm})$ & Simulation & Model type \\
& 2.4 & Regression \\
\hline 0 & 2.3 & 1.49 \\
5 & 1.89 & 1.81 \\
10 & & 2.4 \\
\hline
\end{tabular}

Figure 2 shows an example of simulated temperature dynamics and fit to data. Temperature at $3 \mathrm{~m}$ depth had a mean of $-17^{\circ} \mathrm{C}$, amplitude of $14^{\circ} \mathrm{C}$ and minimum daily mean in early October. This compares well to $3 \mathrm{~m}$ temperatures observed in Wright Valley (Thompson et al. 1971) which had a mean of $-19^{\circ} \mathrm{C}$, amplitude of $14^{\circ} \mathrm{C}$ and minimum monthly mean in September. Table IV gives a quantitative measure of the fit of the simulation model to data. For the tuning sets, the fraction of variation in dependent variable accounted for by the model $\left(\mathrm{R}^{2}\right)$ ranged from 0.97 to 0.99 for soil temperature. The $\mathrm{R}^{2}$ for incoming and emitted longwave radiation (Bonney site only) were 0.57 and 0.97 , respectively. Table V compares observed and simulated degree days. The simulation accounted for $99 \%$ of the variation in observed degree days at the Bonney site and $96 \%$ at Fryxell.

Regression models predicting daily average soil temperature were developed using only the tuning datasets. Table VI gives the regression models and fits to soil temperature data. The models accounted for more than $97 \%$ of the variation in soil temperature, and residual error ranged between $1.2-2.3^{\circ} \mathrm{C}$. All driving variables of the simulation model contributed significantly to the regression models, except for wind speed at the Hoare site and relative humidity at all sites. The effect of reflected shortwave radiation was inconsistent and did not contribute significantly after incoming radiation was in the equations. The variables "Day" (Julian day) and Day ${ }^{2}$ were included to force a

Table VI. Regression models for daily mean soil temperature $\left({ }^{\circ} \mathrm{C}\right)$ and the fit to data for tuning sets.

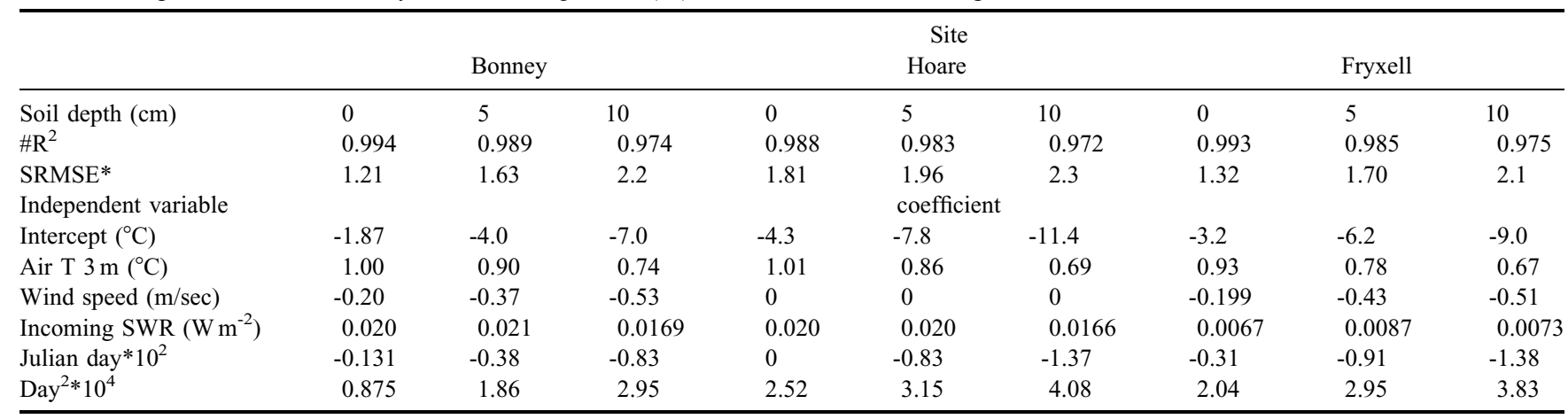

$\# \mathrm{R}^{2}$ is the fraction of variation of the dependent variable accounted for by the regression model.

*SRMSE is the square root of the mean squared error. 
Table VIII. Residual error (square root of mean squared error, ${ }^{\circ} \mathrm{C}$ ) for simulation and regression model predictions of soil temperature at the same site used for model development vs at different sites. The two-way interaction is significant at $P<0.0001$.

\begin{tabular}{lcc}
\hline Data from: & Simulation & Model type \\
& 2.21 & Regression \\
\hline Same site & 2.43 & 1.91 \\
Different sites & & 2.64 \\
\hline
\end{tabular}

seasonal pattern. The signs of coefficients were generally consistent across sites and depths.

The residual errors of regression and simulation models for temperature data and the predictive power of these models were compared using two kinds of statistical tests. In the first (within sites) test, the fit of models to data used for model development (tuning sets) was compared to the fit for data that were from the same site but not used for parameter estimation (validation sets). Seven sets of data (combinations of site and depth) allowed for a balanced ANOVA design for comparing tuning and validation sets. The interaction between model type (regression vs simulation) and dataset was significant, with the regression models fitting better for surface temperature and simulation models fitting better at $10 \mathrm{~cm}$ depth. Surprisingly, the fit was not significantly better $(P<0.35)$ for the tuning sets than the validation sets. Disregarding the distinction between tuning and validation sets allowed the inclusion of two additional datasets (surface temperatures at Hoare and Fryxell). Analysis of all nine datasets confirmed the depth by model type interaction (Table VII). The second (across sites) test evaluated the ability of models to predict temperatures at sites different from the site used for parameter estimation (Table VIII). The regression models better predicted temperatures at the same site used for model development, while the simulation model better predicted temperatures at different sites.

\section{Long-term trends}

Statistical tests for temporal trends at the three sites employed seasonally averaged variables $(5 \mathrm{~cm}$ soil temperature, degree days, $3 \mathrm{~m}$ air temperature, incoming shortwave radiation, wind speed and albedo) vs date for each of two seasons. Within each site, data were included only for time periods which had no missing daily mean observations over multiple years. There were between four and nine such time periods for different sites between 1994 and 2005. We tested for the significance of temporal trends using analysis of covariance (programme 1V, Dixon 1985) with year as the covariate and six classification groups defined by three sites and two seasons. Mean values of the dependent variables varied significantly with season and site, the latter effect partly attributable to defining seasons differently for different sites. However, the slopes of the covariate (temporal trends)

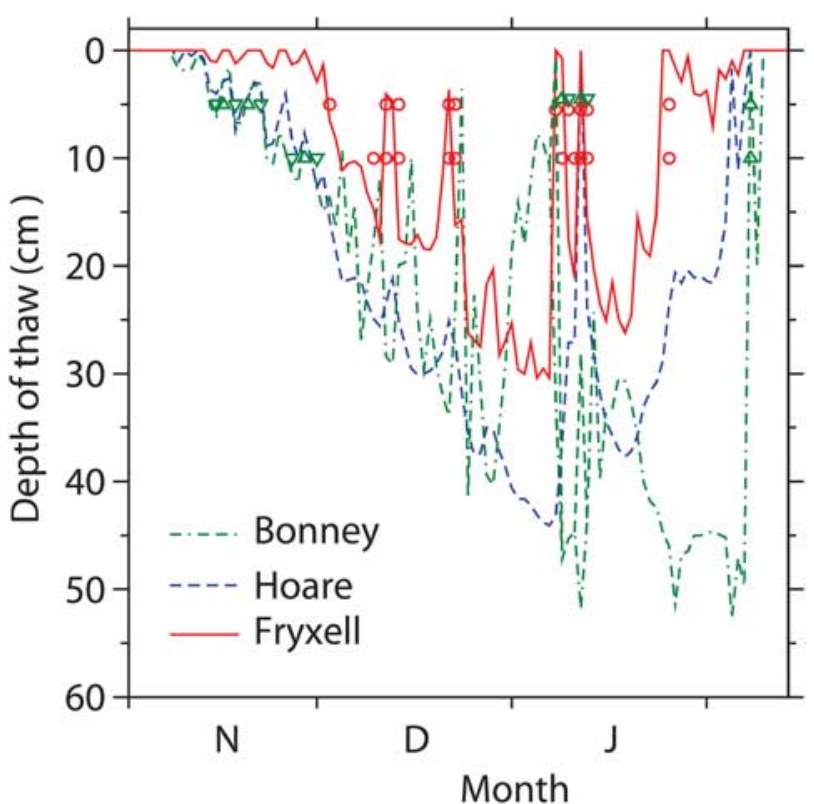

Fig. 3. Simulated daily average depth of $0^{\circ} \mathrm{C}$ estimated by interpolation between layers for 1996-97. Observed sign changes of daily average temperature at 5 and $10 \mathrm{~cm}$ depth are indicated for the Bonney (triangles) and Fryxell (circles) sites.

did not differ significantly from zero and did not vary significantly among sites or seasons for any variable. Only wind speed approached significance $(P<0.08)$ with a decline of $0.40 \mathrm{~m} \mathrm{sec}^{-1} \mathrm{decade}^{-1}$. Table $\mathrm{V}$ gives predicted and observed degree days (calculated based on average daily temperatures) for years with complete summer season records. Degree days calculated using 15-20 minute intervals yielded $10 \%$ greater sums, but results of the two

Table IX. Response of simulated maximal seasonal depth of thaw $(\mathrm{cm})$ to elevated air temperature $\left(+2^{\circ} \mathrm{C}\right)$.

\begin{tabular}{|c|c|c|c|c|c|c|}
\hline \multirow[t]{3}{*}{ Year } & \multicolumn{6}{|c|}{ Site } \\
\hline & \multicolumn{2}{|c|}{ Bonney } & \multicolumn{2}{|c|}{ Hoare } & \multicolumn{2}{|c|}{ Fryxell } \\
\hline & Obs. ${ }^{1}$ & Elev. $^{2}$ & Obs. & Elev. & Obs. & Elev. \\
\hline 1993-94 & & & 30.3 & 35.4 & & \\
\hline 1994-95 & & & & & 19.9 & 29.9 \\
\hline 1995-96 & 69.8 & 87.7 & & & 30.8 & 46.8 \\
\hline 1996-97 & 55.3 & 77.9 & & & 32.7 & 46.6 \\
\hline 1997-98 & 52.4 & 68.1 & & & 28.9 & 43.5 \\
\hline 1998-99 & & & & & 29.9 & 47.5 \\
\hline 1999-2000 & 51.4 & 79.7 & & & 22.4 & 39.5 \\
\hline $2000-01$ & & & & & 17.7 & 29.0 \\
\hline $2001-02$ & 78.7 & 90.1 & & & & \\
\hline $2002-03$ & 49.0 & 70.1 & 34.2 & 47.6 & 19.9 & 33.9 \\
\hline 2003-04 & 62.3 & 88.2 & 32.8 & 49.6 & 28.7 & 37.4 \\
\hline 2004-05 & 50.3 & 76.9 & 30.6 & 46.4 & 19.3 & 33.9 \\
\hline Mean & 58.1 & 78.6 & 32.0 & 44.8 & 25.0 & 38.8 \\
\hline S.D. & 11.5 & 8.2 & 1.9 & 6.4 & 5.7 & 7.1 \\
\hline
\end{tabular}

${ }^{1}$ Model driven with observed air temperatures.

${ }^{2}$ Model driven with year-around elevated air temperatures. 


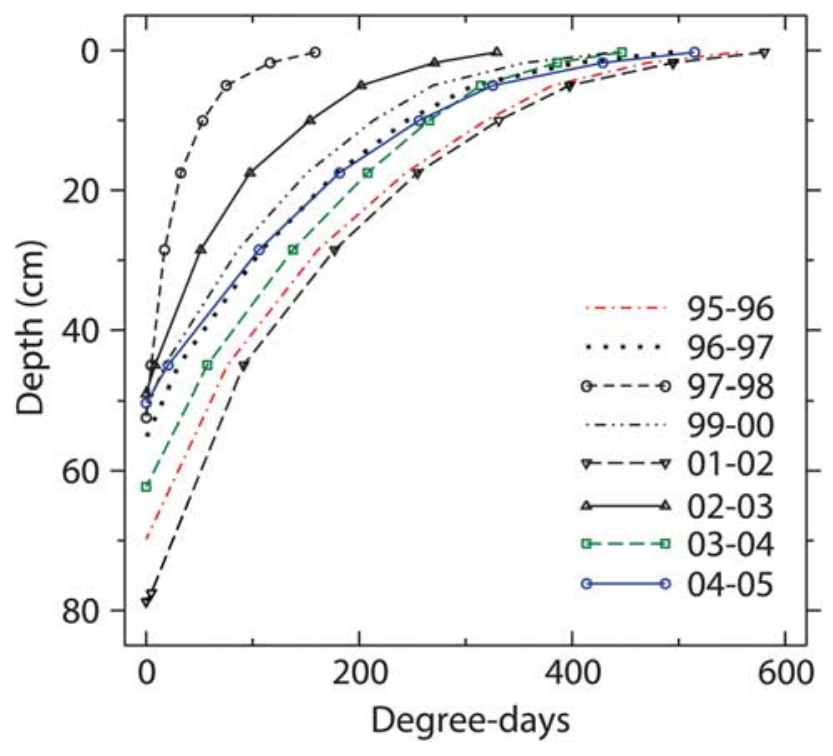

Fig. 4. Simulated depth distribution of degree days $\left(0^{\circ} \mathrm{C}\right.$ base $)$ at the Bonney site for selected years. The model was driven with observed air temperatures.

methods were highly correlated $(r>0.998)$. For the six years with degree day records at both Bonney and Fryxell, ANOVA showed that most of the variation $(85 \%)$ was associated with site $(P<0.0001)$, but that year was also significant $(P<0.003)$. However, linear temporal trends were not significant $(P<0.52)$ at either site. There were significantly $(P<0.005)$ more freeze events per year at the Fryxell site (5.0) than at Bonney (2.5), but no significant temporal trends $(P<0.17)$.

\section{Depth of thaw}

Simulated depth of thaw was surprisingly dynamic (Fig. 3), changing as much as $35 \mathrm{~cm}$ over a few days. Annual maximal depth of thaw was attained by early January at the Fryxell and Hoare sites, but not until early February at Bonney. Table IX shows estimated maximal depth of thaw for all years under both observed and elevated temperatures. The effect of elevated temperature on depth of thaw at the colder sites was less in absolute terms, but greater in relative terms. To determine the time required for the system to equilibrate to elevated temperatures, we made a ten year model run for the Bonney site using driving variables for 2003-04 repeated year after year. Depth of thaw virtually stabilized by the second season for both observed temperatures ( $54 \mathrm{~cm}$ to permafrost) and elevated temperatures ( $77 \mathrm{~cm}$ to permafrost). Figure 4 shows the depth distribution of degree days for summer seasons at the Bonney site with complete records of driving variables. Degree days declined rapidly with depth - by about $50 \%$ in the top ten centimetres. Seasons with similar depth of thaw could have very different degree days in the surface layers (e.g. 1997-98 and 2004-05).

\section{Energy budgets}

Table $\mathrm{X}$ shows aggregated energy budgets for the top $(0.5 \mathrm{~cm}$ thick) layer of rock, soil and snow. The site trend in annual shortwave radiation results mainly from less cloud cover at sites farther from the ocean (Bonney), although shortwave radiation at the Hoare site is also reduced by shading from nearby mountains (Doran et al. 2002a). The site patterns in annual net longwave radiation and sensible heat exchange result largely from the trend in surface temperature (Bonney $>$ Hoare $>$ Fryxell). The sum of annual net longwave and shortwave radiation is positive at all three sites, which agrees with estimates from the Wright Valley (Thompson et al. 1971). Both the annual energy balance (net) and the annual net heat conduction between the top two layers are small components of the budget, indicating that the system is near a steady state on

Table X. Simulated surface energy budgets $\left(\mathrm{W} \mathrm{m}^{-2}\right.$ ) for the period from 9 July 1996-8 July 1998. Positive flows add heat to the surface layer $(0-0.5 \mathrm{~cm})$. The "summer day" was taken as the first day in the spring when average daily soil temperature at $10 \mathrm{~cm}$ depth exceeded $10^{\circ} \mathrm{C}\left(1{ }^{\circ} \mathrm{C}\right.$ at Fryxell). The first winter day was when $10 \mathrm{~cm}$ soil temperature first dropped below $-10^{\circ} \mathrm{C}$, and the second winter day was when incoming shortwave radiation first fell below $1 \mathrm{~W} \mathrm{~m}^{-2}$.

\begin{tabular}{|c|c|c|c|c|c|c|c|}
\hline Site & Period & $\begin{array}{l}\text { Net shortwave } \\
\text { radiation }\end{array}$ & $\begin{array}{l}\text { Net longwave } \\
\text { radiation }\end{array}$ & $\begin{array}{c}\text { Sensible heat } \\
\text { exchange }\end{array}$ & $\begin{array}{l}\text { Soil heat } \\
\text { conduction }\end{array}$ & Latent heat & Net \\
\hline \multirow[t]{4}{*}{ Bonney } & Year & 86 & -66 & -13.6 & -2.3 & -3.0 & 0.069 \\
\hline & Summer day & 273 & -103 & -118 & -38 & -4.8 & 9.8 \\
\hline & Winter day 1 & 44 & -72 & -10.0 & 39 & 0.17 & 1.78 \\
\hline & Winter day 2 & $<1$ & -54 & 6.0 & 45 & 0.09 & -1.43 \\
\hline \multirow[t]{2}{*}{ Hoare } & Year & 61 & -48 & -9.2 & -0.62 & -4.0 & -0.40 \\
\hline & Summer day & 276 & -92 & -116 & -42 & -7.2 & 18.5 \\
\hline \multirow[t]{4}{*}{ Fryxell } & Year & 56 & -44 & -0.38 & -1.66 & -10.2 & -0.156 \\
\hline & Summer day & 194.1 & -63 & -58 & -38 & -19.2 & 16.5 \\
\hline & Winter day 1 & 37 & -41 & -10.9 & 15.4 & -1.0 & -0.10 \\
\hline & Winter day 2 & $<1$ & -5.8 & -1.0 & 6.5 & -0.2 & -0.39 \\
\hline
\end{tabular}




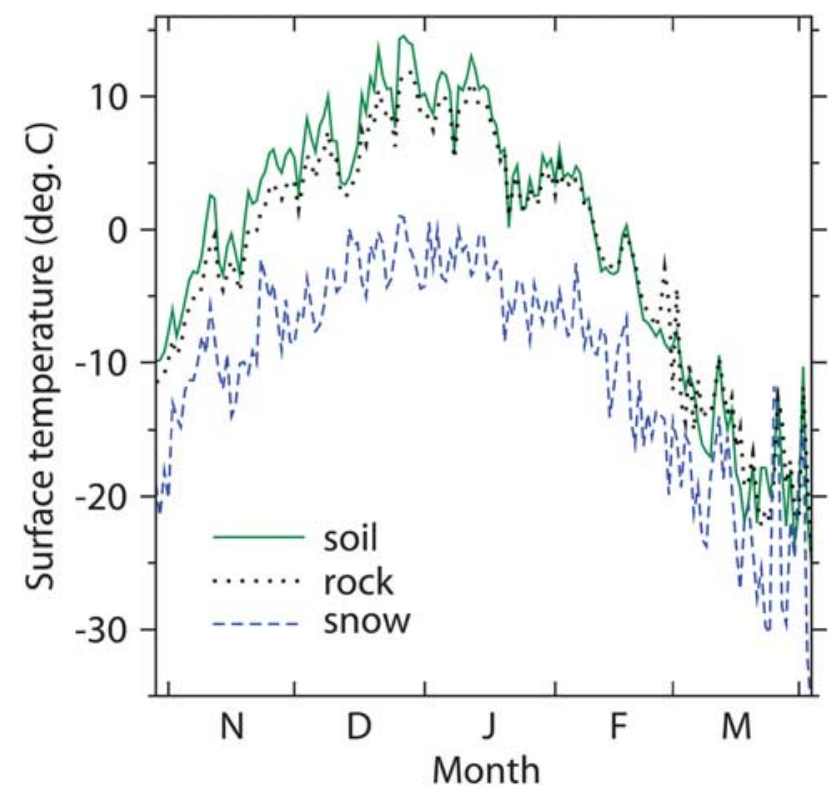

Fig. 5. Simulated surface $(0-0.5 \mathrm{~cm})$ temperatures at the Bonney site in 2001-02.

an annual basis. Latent heat fluxes are small because the sites are very dry. This may help explain the rapid changes in depth of thaw predicted for the Bonney site (above). At all three sites, longwave radiation caused a net cooling of the surface most of the time. On summer days, the surface lost sensible heat to the atmosphere at a rate comparable to the loss via longwave radiation. As winter progressed, sensible heat exchange declined in absolute value and turned positive after the sun disappeared. Heat conduction between the first and second layers followed a predictable seasonal pattern at all three sites. In summer when the surface layer was heated by shortwave radiation, surface soil temperature usually exceeded rock temperature by up to $3^{\circ} \mathrm{C}$ (Fig. 5) because the dry surface soil conducts heat more slowly and has a lower heat capacity than rock. Thus

Table XI. Simulated water transfers $\left(\mathrm{cm} \mathrm{yr}^{-1}\right)$ involving the top layer. The transfers were calculated over a unit area of ground (snow, bare soil and bare rock), rather than for bare soil only. Positive transfers add water to the top layer. The model was run for two years beginning 9 July 1996.

\begin{tabular}{lccc}
\hline Transfer & \multicolumn{3}{c}{ Site } \\
& Bonney & Hoare & Fryxell \\
\hline Snowmelt & 1.73 & 2.85 & 3.42 \\
Vapour from snow cover & 0.21 & 0.31 & 0.93 \\
Evaporation & -1.94 & -3.16 & -4.34 \\
Potential evaporation $^{1}$ & -28 & -20 & -19.3 \\
Soil vapour flow $^{\text {Capillary flow }}$ & +0.0076 & -0.0033 & -0.0021 \\
\hline
\end{tabular}

${ }^{1}$ This was estimated by running the model with a continuous input of water to keep the top soil layer saturated.

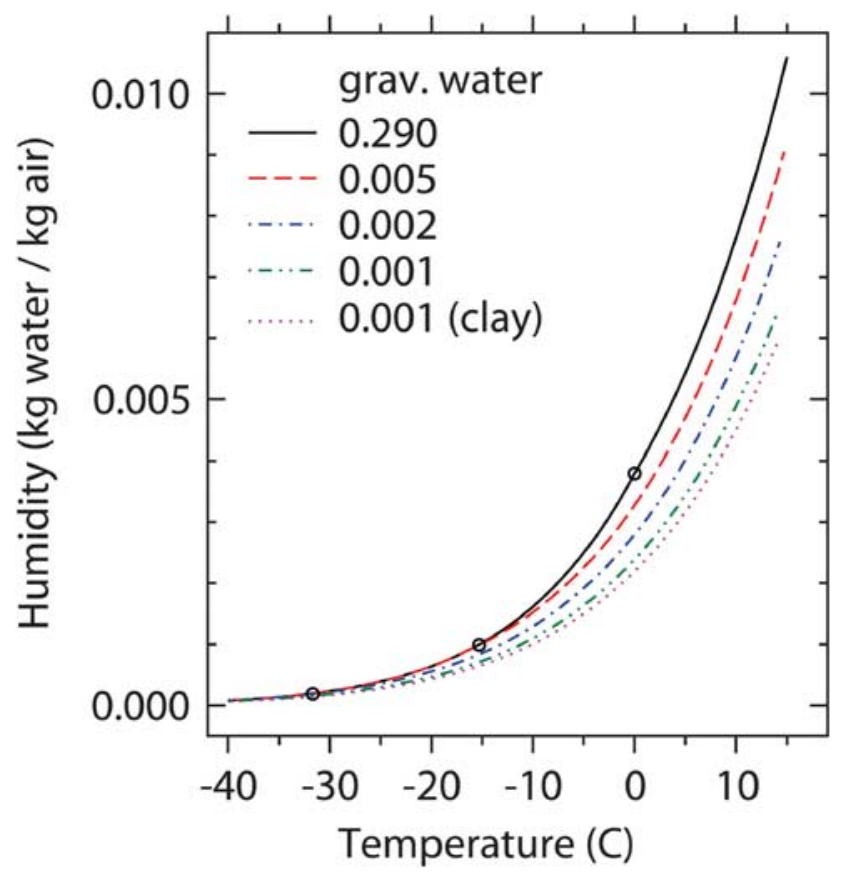

Fig. 6. Effects of temperature and gravimetric soil water ( $g$ water per $g$ dry soil) on specific humidity in soil air. The upper four lines are for a typical McMurdo Dry Valley soil with $95 \%$ sand and $2.3 \%$ clay. The bottom line is for a soil with $86 \%$ sand and $6.1 \%$ clay, within the range of variation for the Dry Valleys (Hunt et al. 2007). Circles indicate freezing temperatures for the upper three lines. The two driest soils freeze at below $-40^{\circ} \mathrm{C}$.

in summer, heat was transferred from soil to rock at rates up to $0.5 \mathrm{~W} \mathrm{~m}^{-2}$. In winter, surface temperature of soil differed from rock by $\pm 5-7^{\circ} \mathrm{C}$ (depending on wind speed and the difference between air and surface temperatures) and heat transfers between rock and soil were $\pm 10-15 \mathrm{~W} \mathrm{~m}^{-2}$. There was a small annual net heat transfer of $0.57 \mathrm{~W} \mathrm{~m}^{-2}$ from rock to soil in the surface $(0-0.5 \mathrm{~cm})$ layer, but there was little difference between rock and soil temperatures below $3 \mathrm{~cm}$ depth.

\section{Water budgets}

Precipitation in the floors of the McMurdo Dry Valleys appears to be quite low, perhaps about $1.3 \mathrm{~cm} \mathrm{yr}^{-1}$ (Beyer et al. 1999). We did not use the precipitation data available for our sites because these data are difficult to interpret (Harris et al. 2007). Most precipitation comes as snowfall, and much of it appears to be lost via sublimation and wind ablation (Campbell \& Claridge 2006). Thus snow cover does not automatically lead to water input to soil. Table XI gives our estimates of liquid and vapour transfers at the surface. The largest water inputs came from melting snow, which varied among sites from $1.7-3.4 \mathrm{~cm} \mathrm{yr}^{-1}$ in proportion to estimated snow cover. Vapour movement 


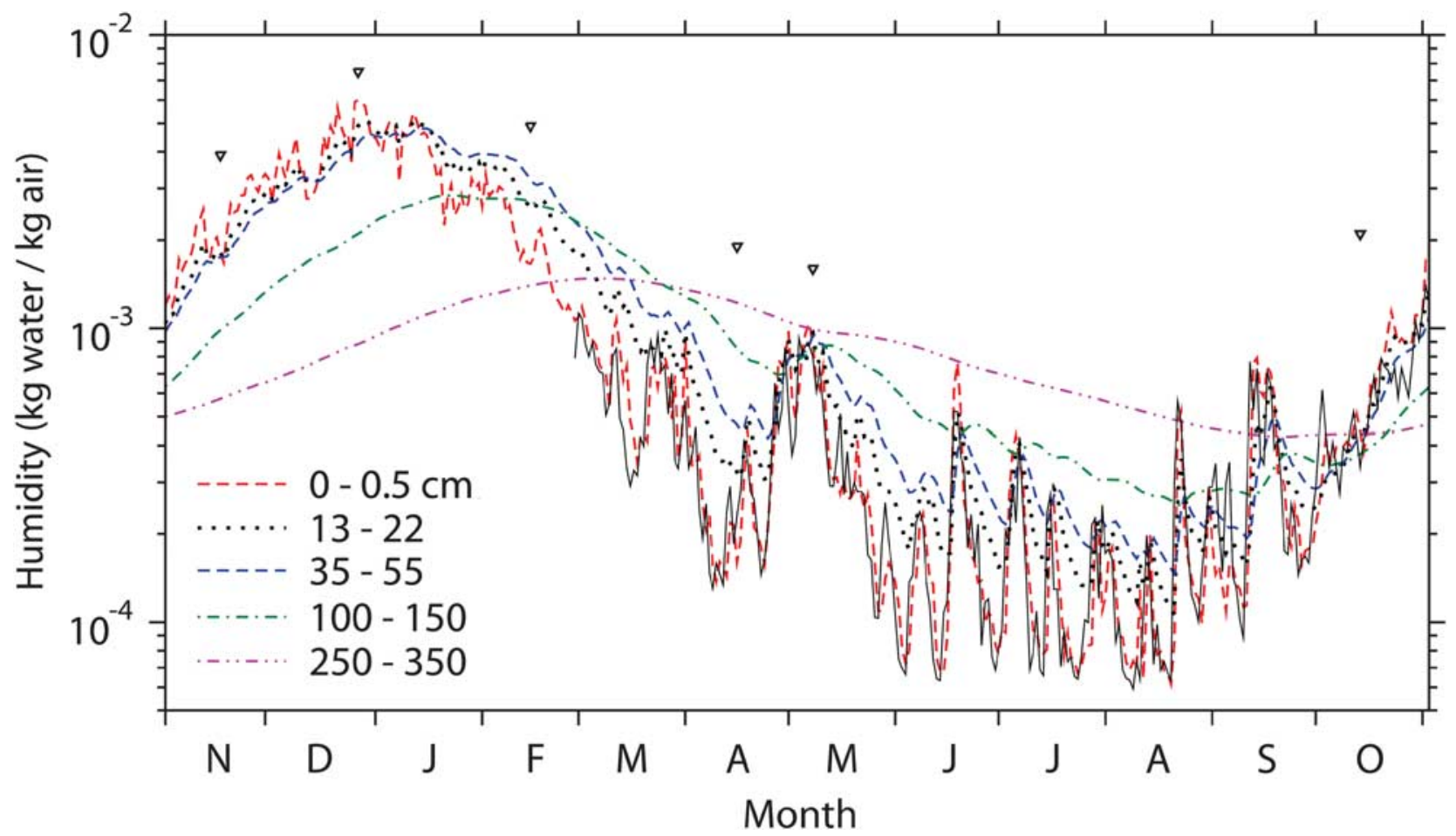

Fig. 7. Simulated dynamics of water vapour for selected soil layers at the Bonney site in 2002-03. Triangles indicate dates for which detailed humidity gradients are presented in Fig. 8.

from snow to underlying soil was smaller, but was as great as $27 \%$ of snowmelt at the Fryxell site. Potential evaporation was simulated by adding a continuous water supply to the top soil layer, but disallowing capillary flow to avoid altering soil heat conduction. Gooseff et al. (2003) estimated open pan evaporation north of the Hoare site for 11 January 2000 as $0.62 \mathrm{~cm} \mathrm{day}^{-1}$, which compares well to the model estimate of $0.51 \mathrm{~cm} \mathrm{day}^{-1}$ for the Hoare site on the same date. Potential evaporation at these sites was large compared to the simulated rate of snowmelt, and thus there was no water infiltration below the surface layer. Daily fluxes of soil vapour, either upward or downward, had a maximal magnitude of $<0.002 \mathrm{~cm} \mathrm{day}^{-1}$. Annual net vapour flux between the surface layer and the underlying soil was upward at the Bonney site, and downward at the Hoare and Fryxell sites.

McMurdo Dry Valley soils may have water contents below $0.1 \%$ gravimetric (Hunt et al. 2007). Thawed dry soil may have higher water potential than ice, even at low soil water contents (cf. Schorghofer \& Aharonson 2005). This is illustrated for our model in Fig. 6. The wettest soil is at saturation (zero water potential) and thus freezes at $0^{\circ} \mathrm{C}$ (assuming zero osmotic potential, as in the present model). The soil with $0.005 \mathrm{~g}$ water per gram dry soil freezes at about $-15^{\circ} \mathrm{C}$, and below that temperature the curve merges with that for the saturated soil, because ice is present in both. The very dry clay soil (6.1\% clay, bottom line) has a greater vapour pressure than saturated soil at $0^{\circ} \mathrm{C}$ if the dry soil is warmer than about $8^{\circ} \mathrm{C}$, a value commonly reached in many Dry Valley surface layers. At $1 \%$ gravimetric water, soil warmer than $2^{\circ} \mathrm{C}$ has greater vapour pressure than ice at $-25^{\circ} \mathrm{C}$ for a range of sandy textures.

Figure 7 shows that simulated water vapour concentrations in summer were high and variably dependent on depth

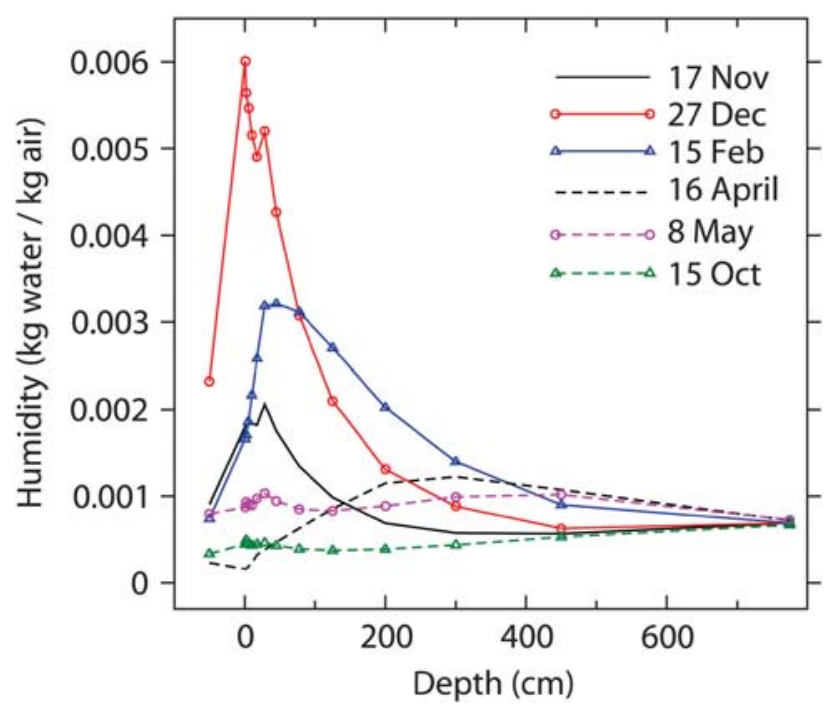

Fig. 8. Simulated humidity gradients for selected dates at the Bonney site in 2002-03. The values plotted above zero depth are observed air humidity at $3 \mathrm{~m}$. Seasonal dynamics for several depths are given in Fig. 7. 


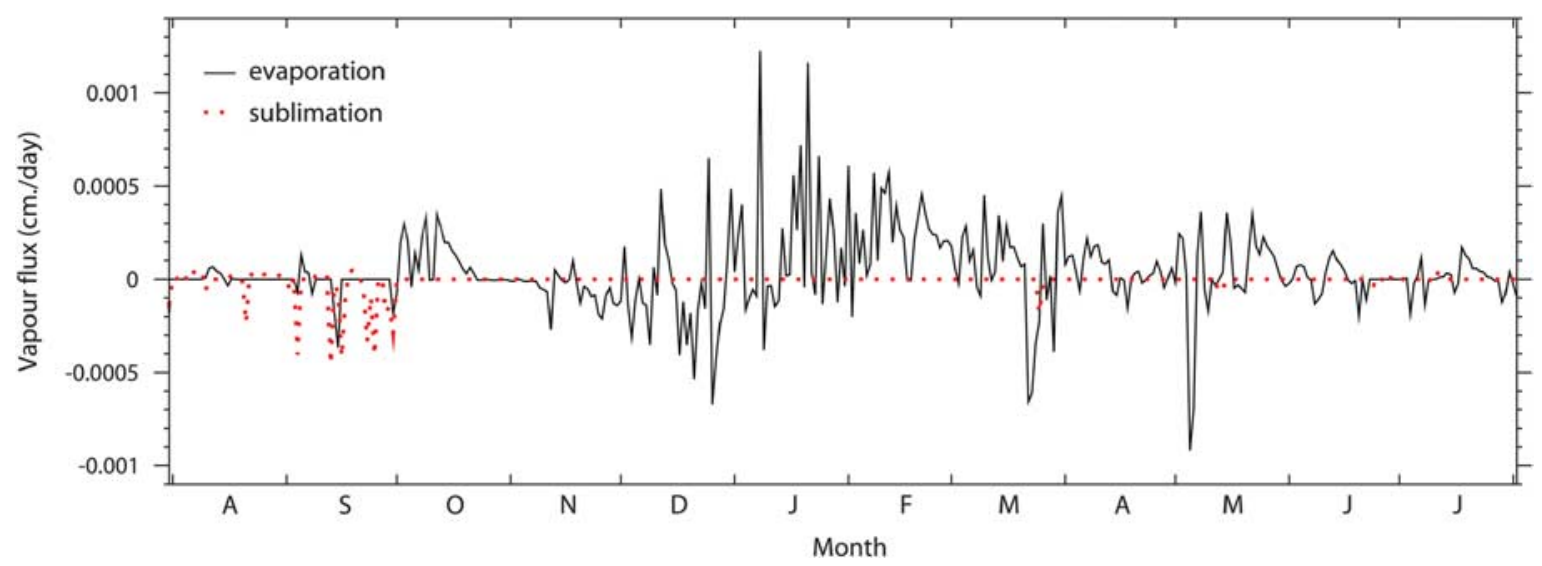

Fig. 9. Vapour fluxes between the first $(0-0.5 \mathrm{~cm})$ and second $(0.5-3 \mathrm{~cm})$ soil layers at the Bonney site. Positive fluxes are upward. Evaporation and sublimation pertain to conditions in the source layer.

through the top $55 \mathrm{~cm}$ of soil, and then declined with depth into the frozen layers. In winter, the gradient was usually reversed with lowest vapour concentrations at the surface. Disruptions of the usual winter pattern (Fig. 7, peaks in the $0-0.5 \mathrm{~cm}$ humidity) were correlated with katabatic winds, as observed in Victoria Valley (Hagedorn et al. 2007). Figure 8 shows the complete gradients for selected dates indicated in Fig. 7. The humidity gradients were smaller, in absolute terms, in winter. The depth of the highest vapour concentration varied over time between the surface (27 December) and $7.75 \mathrm{~m}$ (15 October), but was nearer the surface $(0-50 \mathrm{~cm})$ when the gradients were steepest. In November to February, humidity in the surface layer was appreciably greater than air humidity, which would speed vapour exchange between soil and atmosphere, but slow exchange within the soil. Figure 9 shows daily vapour fluxes between the first two soil layers. Fluxes could be either upward or downward any season of the year, although sublimation was predominantly downward. Evaporation was the predominant process in the top two layers even in winter because these layers were dry and froze only at low temperatures (cf. Fig. 6). Annual net vapour fluxes (Table XII) in the run without irrigation were upward in soil above $22 \mathrm{~cm}$ depth and downward below $35 \mathrm{~cm}$. Capillary flows from layer $7(35-55 \mathrm{~cm})$ to layers 6 and 8 resulted from occasional melting events in layer 7 (Fig. 3). Such meltwater might flow laterally over permafrost (Harris et al. 2007). Water losses from the soil exceeded inputs by $0.148 \mathrm{~mm}$ after 2 years and $0.57 \mathrm{~mm}$ after 4.6 years.

To examine the effect of water infiltration below the surface layer, we simulated the instantaneous addition of $1 \mathrm{~cm}$ of water to the top soil layer in early summer. Water infiltrated relatively deeply (Table XII) because of the high rock content and low field capacity $(c .0 .05 \mathrm{~g}$ water per $\mathrm{g}$ dry soil) of the sandy soil, but no added water infiltrated below $35 \mathrm{~cm}$. Added water held against gravity in the surface layer was lost by evaporation within two days, and that in the $0.5-3 \mathrm{~cm}$ layer within 20 days. In the $3-7 \mathrm{~cm}$ layer, added water was largely lost via evaporation and

Table XII. Simulated effect of a pulse of water on water transfers $\left(\mathrm{mm}\right.$ in two years) in the Bonney profile. In the irrigated run, $10 \mathrm{~mm}$ water at $0^{\circ} \mathrm{C}$ was added instantaneously to the top layer in early summer when the soil surface was thawed. Positive flows are downward.

\begin{tabular}{|c|c|c|c|c|c|c|}
\hline \multirow{2}{*}{ Transfer between } & \multicolumn{3}{|c|}{ Control } & \multicolumn{3}{|c|}{ Water added } \\
\hline & Capillary flow & Evaporation & Sublimation & Capillary flow & Evaporation & Sublimation \\
\hline Snow \& soil & 39.0 & & 3.8 & $48.6^{2}$ & & 3.8 \\
\hline $1(0.5) \& 2^{1}$ & 0 & -0.21 & 0.078 & 8.3 & -3.9 & 0 \\
\hline $2(3) \& 3$ & 0 & -0.137 & 0 & 6.9 & -2.4 & 0 \\
\hline $3(7) \& 4$ & 0 & -0.153 & 0 & 5.4 & -0.54 & -4.7 \\
\hline 4 (13) \& 5 & 0 & -0.194 & 0 & 3.5 & 0.182 & $-5.8 \times 10^{-5}$ \\
\hline 7 (55) \& 8 & 3.1 & 0.0059 & 0.0046 & 4.6 & 0.0083 & 0.0032 \\
\hline $8(100) \& 9$ & 0.30 & 0 & $5.8 \times 10^{-4}$ & 2.1 & 0 & $3.8 \times 10^{-4}$ \\
\hline $9(150) \& 10$ & 0 & 0 & $7.1 \times 10^{-5}$ & 0 & 0 & $7.6 \times 10^{-5}$ \\
\hline
\end{tabular}

${ }^{1}$ Flow between layer $1(0-0.5 \mathrm{~cm})$ and layer $2(0.5-3 \mathrm{~cm})$. Bottom of layer $(\mathrm{cm})$ is given in parentheses.

${ }^{2}$ Includes the $10 \mathrm{~mm}$ added water. 


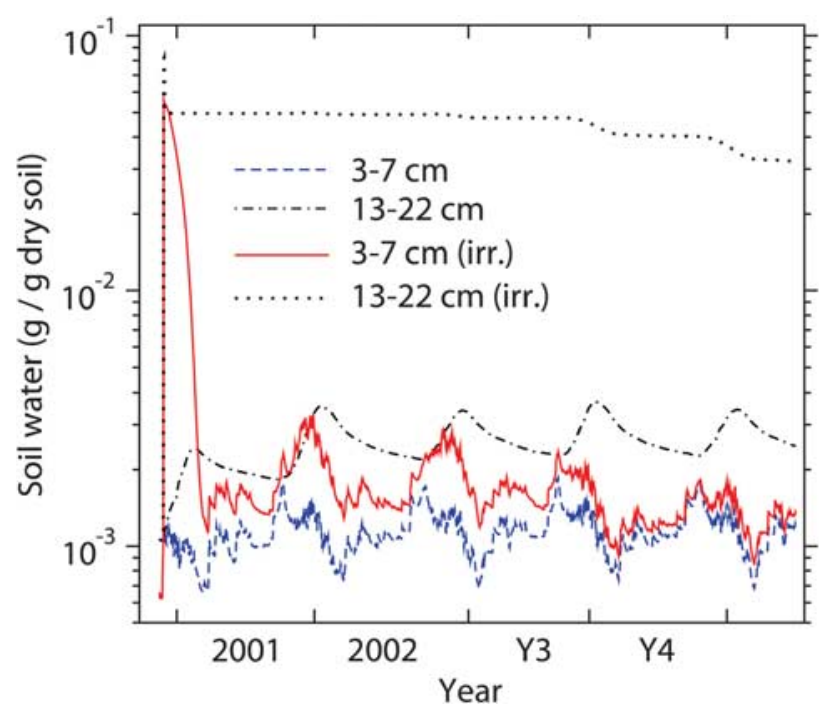

Fig. 10. Simulated effect of a $1 \mathrm{~cm}$ irrigation event on soil water dynamics at the Bonney site. The model was run for 2.6 years using observed driving variables, and then another 2.0 years reusing the same driving variables but beginning on the appropriate day and month.

sublimation within 3.5 months (Fig. 10). The $13-22 \mathrm{~cm}$ layer retained about $0.03 \mathrm{~g}$ water per $\mathrm{g}$ dry soil after 4.6 years. Very little of the water which infiltrated below $22 \mathrm{~cm}$ was lost after 4.6 years. The soil still retained $0.44 \mathrm{~cm}$ of added water two years after irrigation and $0.30 \mathrm{~cm}$ after 4.6 years. Water addition raised the level in the profile below which vapour flows were downward, and increased the rates of downward vapour flows (Table XII).

If the model is driven using the same weather variables year after year, soil water eventually will approach a constant depth distribution - a steady state depending on snowmelt and the water vapour content of the atmosphere. Soil water changes so slowly that it was impractical to use simulation to examine the approach of soil water from a completely dry state to the steady state. Instead, we found a series of approximations to the approach to steady state based on the assumption that higher layers equilibrate with the source/sink of water before underlying layers do. This approach showed general agreement with simulation in a 300 year model run starting with a fully saturated profile. Figure 11 shows the approximated approach of soil water to steady state from either dry or saturated initial states. Equilibration to within $2 \%$ of steady state occurred much faster beginning from saturation (269 years) than from a dry state (42000 years).

\section{Sensitivity analysis}

The sensitivity of the simulation model to driving variables and to selected processes and parameters was evaluated using the Bonney model. In Table XIII, the first two

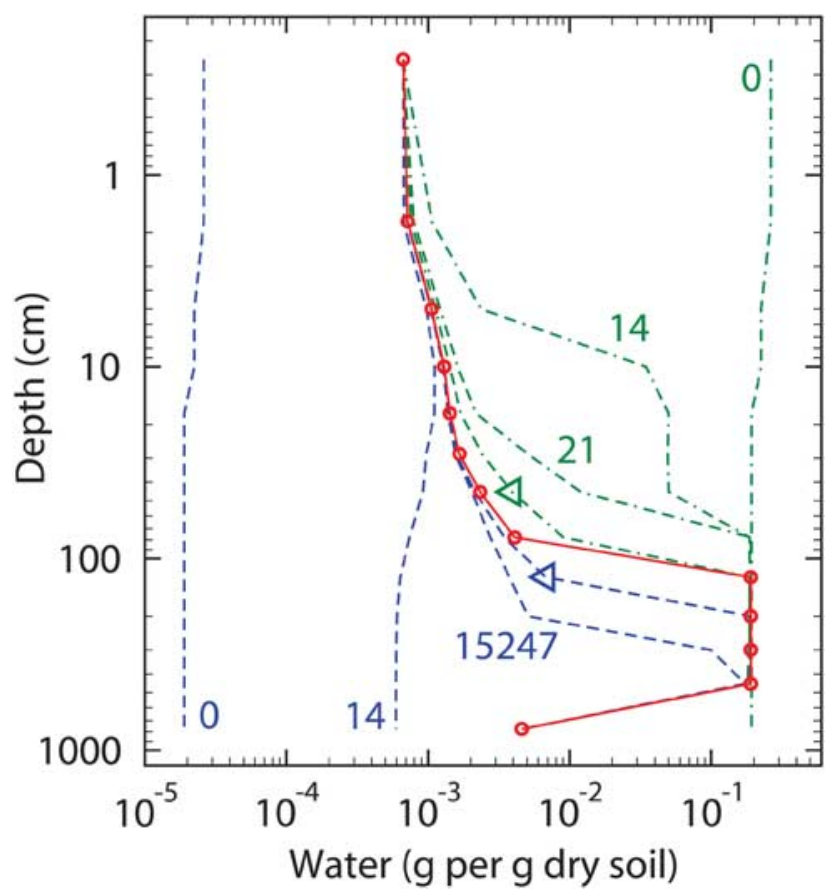

Fig. 11. The dynamics of the depth distribution of water in two situations beginning with either: 1) dry soil (blue dashed lines), or 2) wet soil (green dot-dashed lines). The steadystate distribution is given by the solid red line with circles, the circles indicating the mid-points of soil layers. Numbers indicate the years required to reach the indicated depth distribution. The last depth distribution shown for the first simulation (blue dashed line indicated by triangle) occurred after 25208 years, and the last shown for the second simulation (green dot-dashed line indicated by triangle) occurred after 269 years.

indicators of model response ( $\mathrm{R}^{2}$ and degree days) were used in estimating parameters, but the second two (depth of thaw and evaporation) were not, because we lacked data for those indicators. Beneath the standard run (first entry in the table), entries are ordered according to absolute departure from degree days in the standard run. Heat exchange between the top $22 \mathrm{~cm}$ and the ground beneath had a large effect in cooling surface layers in summer and warming them in winter. Decreasing the roughness length increased sensible heat exchange with the atmosphere and cooled the ground surface in summer, reducing depth of thaw and evaporation. The fraction and properties of rocks had large effects on the model, but we have little information on rock content at the meteorological stations. Among the driving variables, only air temperature appreciably affected degree days or $\mathrm{R}^{2}$. Reducing soil emissivity led to reduced longwave emission and increased soil warming in summer. The above five alterations caused the largest departures for degree days and also tended to cause larger reductions in $R^{2}$. In the lower portion of the table, all 14 
Table XIII. Simulation model response to altered driving variables and model processes. Results are from a two-year run of the Bonney model beginning 17 November 2000 .

\begin{tabular}{|c|c|c|c|c|}
\hline Alteration ${ }^{1}$ & $\begin{array}{l}\text { Fit }\left(\mathrm{R}^{2}\right) \text { to temp. } \\
\quad \text { data }(5 \mathrm{~cm})\end{array}$ & $\begin{array}{l}\text { Degree days } \\
5 \mathrm{~cm} \text { depth }\end{array}$ & $\begin{array}{l}\text { Maximal depth } \\
\text { of thaw }(\mathrm{cm})\end{array}$ & $\begin{array}{c}\text { Evaporation } \\
\left(\mathrm{cm} \mathrm{yr}^{-1}\right)\end{array}$ \\
\hline None & 0.978 & 328 & 79 & 1.93 \\
\hline No heat flow below $22 \mathrm{~cm}$ & 0.916 & 583 & 22 & 2.41 \\
\hline Roughness length $=0.03(0.0010)$ & 0.965 & 96 & 45 & 0.77 \\
\hline Air temperature +2 deg. $\mathrm{C}$ & 0.955 & 471 & 89 & 2.57 \\
\hline Fraction surface rock $=0.8(0.45)$ & 0.984 & 394 & 84 & 1.89 \\
\hline Soil emissivity x 0.76 & 0.972 & 381 & 82 & 2.20 \\
\hline Rock/soil albedo $=0.11(0.066)$ & 0.978 & 292 & 66 & 1.77 \\
\hline Cloud cover $+20 \%$ & 0.978 & 298 & 67 & 1.80 \\
\hline Wind speed $+10 \%$ & 0.978 & 303 & 78 & 1.82 \\
\hline No water or latent heat flows & 0.978 & 350 & 82 & 0 \\
\hline $\mathrm{wmin}^{2}=0.00001(0.005)$ & 0.978 & 308 & 58 & 2.13 \\
\hline Add water to top layers & 0.977 & 347 & 82 & 2.10 \\
\hline Richardson number x 0.85 & 0.978 & 333 & 80 & 1.96 \\
\hline Relative humidity $-10 \%$ & 0.978 & 328 & 80 & 1.94 \\
\hline
\end{tabular}

${ }^{1}$ For parameters, standard values are given in parentheses.

${ }^{2}$ wmin is the value of volumetric soil water below which water fluxes in a layer are suspended to reduce computer run time.

alterations had high $\mathrm{R}^{2}$ and degree days within $15 \%$ of the standard run. Nevertheless, maximal depth of thaw in these 14 runs varied from $18-99 \mathrm{~cm}$, and evaporation from $0.0-2.6 \mathrm{~cm}$. Thus wide variation in predictions of evaporation and depth of thaw are compatible with good fits to the temperature data. Campbell \& Claridge (2006) identified albedo as a critical variable affecting Dry Valley soil temperature, but increasing albedo from 0.066 to 0.11 in the model had a relatively small cooling effect, because it caused only a 5\% decline in absorbed shortwave radiation. Alterations affecting water supply and water fluxes had little effect on temperature because the system is so arid.

\section{Discussion}

The simulation model fitted the observed soil temperature data well, except that the model tended to overestimate surface temperatures in winter by a few degrees. This problem may have resulted from errors in specifying the depth distributions of rocks and water, which control thermal properties, but which were not based on information specific to our sites. Thermal properties of the ground are known to vary across sharp compositional boundaries at some sites in the McMurdo Dry Valleys (Pringle et al. 2003). Overestimating winter surface temperatures will have little effect on simulated water vapour transfers because the effect of temperature on water vapour pressure is small below $-30^{\circ} \mathrm{C}$, and because depth gradients of vapour pressure are smallest in winter. The regression models fitted the temperature data better than the simulation models, at least when applied to the same site used for model specification. This difference probably results from including imperfectly known structures and processes in the simulation model, for example the depth distribution of thermal properties. Of course the regression models do not treat soil water and lack the heuristic value of the simulation model.

Doran et al. (2002b) found significant decreases in air temperature and wind speed between 1986 and 2000 at the Hoare site. We found no significant temporal trends for air temperature or soil temperature at any of three Taylor Valley sites including Hoare, although a decline in wind speed was almost significant. However, our analyses were not strictly comparable to theirs because we analysed fewer years and a more recent time period.

Simulated depth of thaw was quite variable within and between seasons. Seasonal maximal depth of thaw at the Bonney site for $2001-02(79 \mathrm{~cm})$ was somewhat greater than the value of $61 \mathrm{~cm}$ estimated for the same site for 2001-02 by Lyons et al. (2005) using a simple model driven by average annual air temperature. The range of seasonal maximal depth of thaw over sites and years predicted by our model was $18-79 \mathrm{~cm}$. Reported ranges of seasonal depth of thaw based on data from soil pits include $20-100 \mathrm{~cm}$ for coastal Dry Valleys (French \& Guglielmin 2000 ), and $10-65 \mathrm{~cm}$ for both coastal and upland sites (Campbell et al. 1997b). These studies were not based on multiple observations over dates in late summer, and thus probably underestimate depth of thaw (Campbell \& Claridge 2006). Moorhead et al. (2002) suggested that 
Dry Valley nematode populations require about 50 degree days per year to sustain their populations, and that nematodes are most abundant between 2.5 and $10 \mathrm{~cm}$ depth. Our results from the Bonney site indicate that soil below $10 \mathrm{~cm}$ would accumulate less than 50 degree days in some (one of eight) years, and that soil above $3 \mathrm{~cm}$ could dry (halting nematode activity) within 20 days of being wetted. Thus the model supports the conclusion of Moorhead et al. (2002) that temperature and water patterns may account for depth distribution of nematodes.

French \& Guglielmin (2000) cited an estimate by T.J.H. Chinn of $18 \mathrm{~cm}$ potential annual evaporation in a coastal Dry Valley region. This is close to our estimate of $19 \mathrm{~cm}$ at the Fryxell site, the closest to the coast of our three sites. Our simulated rate of snowmelt was too slow to overcome the high evaporation demand and allow water to infiltrate below the surface layer. Indeed, we have no direct evidence for water infiltration at our meteorological sites for the years studied. The best way to estimate precipitation inputs to soil may be to monitor soil water in surface layers. Kowalewski et al. (2006), applying this method, recorded six soil wetting events at $2 \mathrm{~cm}$ depth in one season in Beacon Valley, but they could not quantify the water inputs. Linking such observations to a mechanistic simulation model should allow simultaneous estimates of evaporation, infiltration and vapour fluxes within the soil.

The model predicted a net gain in soil water at the Hoare $\left(0.084 \mathrm{~mm} \mathrm{yr}^{-1}\right)$ and Fryxell $\left(0.087 \mathrm{~mm} \mathrm{yr}^{-1}\right)$ sites over a two year period, even in the absence of capillary water inputs below the surface layer. At the Bonney site, there was a net loss of $0.074 \mathrm{~mm} \mathrm{yr}^{-1}$, which is smaller than the lower range of previous loss estimates predicted from vapour transport. In contrast to previous vapour models for the McMurdo Dry Valleys, our model calculated water vapour pressure in unfrozen soil using a water release curve. Consequently, relatively dry thawed soil could have higher water vapour pressure than ice, and water vapour fluxes in summer were sometimes downward. Another difference from previous vapour models is that we simulated soil water dynamics, and did not assume that soil water is in equilibrium with a uniform depth gradient of vapour pressure. Our results suggest a highly dynamic depth gradient of vapour pressure. At the Bonney site, a single water input of $1 \mathrm{~cm}$ persisted well beyond five years and reduced evaporative losses originating from below $22 \mathrm{~cm}$. To wet the soil to $13 \mathrm{~cm}$ depth, where added water could persist for three or four years, would require a rapid input (faster than the rate of evaporation) of about $0.26-0.72 \mathrm{~cm}$ water to the soil surface (assuming a range of soil textures typical of the McMurdo Dry Valleys, and 50\% rock content). Such water inputs every few years would prevent the attainment of any uniform humidity gradient, and reduce or reverse the simulated soil water loss at Bonney.

If soil water happened to be at steady state for a particular year, then annual net change in soil water would be zero. Thus water gains at the Hoare and Fryxell sites indicate that simulated soil water is below the steady state level. Soil water is probably rarely at steady state for any given year because of annual weather variation and because climate shifts faster than soil water can approach a new steady state, which requires hundreds or thousands of years. Thus soil water will track climate with a significant lag. Our results also suggest that glacier ice would persist indefinitely once till accumulates to sufficient depth $(100 \mathrm{~cm}$ at the Bonney site) at which the ice is in steady state with inputs from snowmelt and exchanges with atmospheric water vapour. On the other hand, water-saturated soil lying below ancient volcanic ash could form at $100 \mathrm{~cm}$ depth within 40000 years via vapour transport through the ash. Our model does not fully address the question of buried ice because it does not include overburden pressure potential or the formation of ice lenses.

Neither our model nor any of the above cited models for estimating sublimation rates include the effects of the high salt concentrations found in some McMurdo Dry Valley soils. Soil salts likely have important effects such as lowering freezing temperatures, increasing soil water contents for a given water vapour pressure, speeding heat conduction in wetter soils, and altering water vapour gradients and vapour fluxes. However, it may be difficult to evaluate salt models because of the lack of data on salts from sites with meteorological stations. Salt composition may vary with depth in complicated patterns (Claridge et al. 1999). Thermodynamic models provide only equilibrium compositions of soil solutions, while rates of dissolution and crystallization are required for any dynamic model of soil salt solutions. Thus a simple empirical approach may be required.

\section{Acknowledgements}

Research supported by NSF project OPP-0423595, the McMurdo LTER. Chris Gardner provided quality control for the meteorology data. The reviewers (Kevin Hall and James Head) and editor made useful suggestions for improving the manuscript.

\section{References}

Beyer, L., Bockheim, J.G., Campbell, i.B. \& Claridge, G.G.C. 1999. Genesis, properties and sensitivity of Antarctic gelisols. Antarctic Science, 11, 387-398.

Buchan, G.D. 1991. Soil temperature regime. In Sмith, K.A. \& Mullins, C.E., eds. Soil analysis physical methods. New York: Marcel Dekker, 551-612.

Campbell, D.I., MacCulloch, R.J.L. \& Campbell, I.B. 1997a. Thermal regimes of some soils in the McMurdo Sound region, Antarctica. In Lyons, W.B., Howard-Williams, C. \& Hawes, I., eds. Ecosystem processes in Antarctic ice-free landscapes. Rotterdam: Balkema, $45-55$.

CAmpBeLL, I.B. 2003. Soil characteristics at a long-term ecological research site in Taylor Valley, Antarctica. Australian Journal of Soil Research, 41, 351-364. 
Campbell, I.B. \& Claridge, G.G.C. 2006. Permafrost properties, patterns and processes in the Transantarctic Mountains region. Permafrost and Periglacial Processes, 17, 215-232.

Campbell, I.B., Claridge, G.G.C., Balks, M.R. \& Campbell, D.I. 1997b. Moisture content in soils of the McMurdo Sound and Dry Valley region of Antarctica. In Lyons, W.B., Howard-Williams, C. \& Hawes, I., eds. Ecosystem processes in Antarctic ice-free landscapes. Rotterdam: A.A. Balkema, 61-76.

Claridge, G.G.C., Campbell, I.B. \& Balks, M.R. 1999. Movement of salts in Antarctic soils: experiments using lithium chloride. Permafrost and Periglacial Processes, 10, 223-233.

Clauser, C. \& Huenges, E. 1995. Thermal conductivity of rocks and minerals. In AHRENS, T.J., ed. Rock physics and phase relations - a handbook of physical constants. Washington, DC: American Geophysical Union, 105-126.

Dana, G.L., Wharton JR, R.A. \& Dubayah, R. 1998. Solar radiation in the McMurdo Dry Valleys, Antarctica. Antarctic Research Series, 72, $39-64$.

Dixon, W.J. 1985. BMDP statistical software. Berkeley, CA: University of California Press, 734 pp.

Doran, P.T., Dana, G.L., Hastings, J.T. \& Wharton JR, R.A. 1995. McMurdo Dry Valleys Long Term Ecological Research (LTER): LTER automatic weather network (LAWN). Antarctic Journal of the United States, 30(5), 276-280.

Doran, P.T., McKay, C.P., Clow, G.D., Dana, G.L., Fountain, A.G., NyLen, T. \& Lyons, W.B. 2002a. Valley floor climate observations from the McMurdo Dry Valleys, Antarctica, 1986-2000. Journal of Geophysical Research, 107, 10.1029/2001JD002045.

Doran, P.T., Priscu, J.C., Lyons, W.B., Walsh, J.E., Fountain, A.G., McKnight, D.M., Moorhead, D.L., Virginia, R.A., Wall, D.H., Clow, G.D., Fritsen, C.H., McKay, C.P. \& Parsons, A.N. 2002b. Antarctic climate cooling and terrestrial ecosystem response. Nature, 415, 517-520.

Fetter, C.W. 1994. Applied hydrogeology. New York: Macmillan College Publishing, $691 \mathrm{pp}$.

French, H.M. \& Guglielmin, M. 2000. Frozen ground phenomena in the vicinity of Terra Nova Bay, northern Victoria Land, Antarctica: a preliminary report. Geografiska Annaler, 82A, 513-526.

GoosefF, M.N., McKnight, D.M., RunKel, R.L. \& Vaughn, B.H. 2003. Determining long time-scale hyporheic flow paths in Antarctic streams. Hydrological Processes, 17, 1691-1710.

Hagedorn, B., Sletten, R.S. \& Hallet, B. 2007. Sublimation and ice condensation in hyperarid soils: modelling results using field data from Victoria Valley, Antarctica. Journal of Geophysical Research, 112, 10.1029/2006JF000580.

Harris, K.J., Carey, A.E., Lyons, W.B., Welch, K.A. \& Fountain, A.G. 2007. Solute and isotope geochemistry of subsurface ice melt seeps in Taylor Valley, Antarctica. Geological Society of America Bulletin, 119, 548-555.

Hindmarsh, R.C.A., van der Wateren, F.M. \& Verbers, A.L.L.M. 1998. Sublimation of ice through sediment in Beacon Valley, Antarctica. Geografiska Annaler, 80A, 3-4.

Hori, M., Aoki, T., Tanikawa, T., Motoyoshi, H., Hachikubo, A., Sugiura, K., Yasunari, T.J., Eide, H., Storvold, R., Nakajima, Y. \& TAKAHASHI, F. 2006. In-situ measured spectral directional emissivity of snow and ice in the $8-14 \mu \mathrm{m}$ atmospheric window. Remote Sensing of Environment, 100, 486-502.

Hunt, H.W., Antle, J.M. \& Paustian, K. 2003. False determinations of chaos in short noisy time series. Physica $D, \mathbf{1 8 0}, 115-127$.

Hunt, H.W., Treonis, A.M., Wall, D.H. \& Virginia, R.A. 2007. A mathematical model for variation in water retention curves among sandy soils. Antarctic Science, 19, 427-436.

JAYNES, D.B. \& TYLER, E.J. 1984. Using soil physical properties to estimate hydraulic conductivity. Soil Science, 138, 298-305.

Kersten, M.S. 1949. Thermal properties of soils. University of Minnesota Engineering Experiment Station Bulletin, No. 28, 227 pp.
Kondo, J., Saigusa, N. \& SAto, T. 1990. A parameterization of evaporation from bare soil surfaces. Journal of Applied Meteorology, 29, 385-389.

Kowalewski, D.E., Marchant, D.R., Levy, J.S. \& Head, J.W. 2006. Quantifying low rates of summertime sublimation for buried glacier ice in Beacon Valley, Antarctica. Antarctic Science, 18, 421-428.

Lyons, W.B., Welch, K.A., Carey, A.E., Doran, P.T., Wall, D.H., Virginia, R.A., Fountain, A.G., Csatho, B.M. \& Tremper, C.M. 2005. Groundwater seeps in Taylor Valley Antarctica: an example of a subsurface melt event. Annals of Glaciology, 40, 200-206.

MAнRт, L. \& Ек, M. 1984. The influence of atmospheric stability on potential evaporation. Journal of Climate and Applied Meteorology, 23, 222-234.

Marchant, D.R., Lewis, A.R., Phillips, W.M., Moore, E.J., Souchez, R.A., Denton, G.H., Sugden, D.E., Potter Jr, N. \& Landis, G.P. 2002. Formation of patterned ground and sublimation till over Miocene glacier ice in Beacon Valley, southern Victoria Land, Antarctica. Geographical Society of America Bulletin, 6, 718-730.

MatThiAs, A.D. 1990. Simulation of daily energy budget and mean soil temperatures at an arid site. Theoretical and Applied Climatology, 42, $3-17$.

McKay, C.P., Mellon, M.T. \& Friedmann, E.I. 1998. Soil temperatures and stability of ice-cemented ground in the McMurdo Dry Valleys, Antarctica. Antarctic Science, 10, 31-38.

McKay, C.P., Andersen, D.T., Pollard, W.H., Heldmann, J.L., Doran, P.T., Fritsen, C.H. \& Priscu, J.C. 2005. Polar lakes, streams, and springs as analogues for the hydrological cycle on Mars. In Tokano, T., ed. Water on Mars and life. Berlin: Springer, 219-233.

Moorhead, D.L., Wall, D.H., Virginia, R.A. \& Parsons, A.N. 2002. Distribution and life-cycle of Scottnema lindsayae (Nematoda) in Antarctic soils: a modelling analysis of temperature responses. Polar Biology, 25, 118-125.

MurRay, F.W. 1967. On the computation of saturation vapour pressure. Journal of Applied Meteorology, 6, 203-204.

Ng, F., Hallet, B., Sletten, R.S. \& Stone, J.O. 2005. Fast-growing till over ancient ice in Beacon Valley, Antarctica. Geology, 33, 121-124.

Pringle, D.J., Dickinson, W.W., Trodahl, H.J. \& Pyne, A.R. 2003. Depth and seasonal variations in the thermal properties of Antarctic Dry Valley permafrost from temperature time series analysis. Journal of Geophysical Research, 108, 10.1029/2002JB002364.

Priscu, J.C. 1999. Life in the valley of the "dead". Bioscience, 49, 959.

Priscu, J.C. \& Christner, B.C. 2004. Earth's icy biosphere. In Bull, A.T., ed. Microbial diversity and bioprospecting. Washington, DC: American Society for Microbiology, 130-145.

Rawls, W.J., Gimenez, D. \& Groosman, R. 1998. Use of soil texture, bulk density and slope of the water retention curve to predict saturated hydraulic conductivity. Transactions of the American Society of Agricultural Engineers, 41, 983-988.

Schäfer, J.M., Baur, H., Denton, G.H., Ivy-Ochs, S., Marchant, D.R., Schlüchter, C. \& Wieler, R. 2000. The oldest ice on earth in Beacon Valley, Antarctica: new evidence from surface exposure dating. Earth and Planetary Science Letters, 179, 91-99.

SCHORGHOFER, N. 2005. A physical mechanism for long-term survival of ground ice in Beacon Valley, Antarctica. Geophysical Research Letters, 32, 10.1029/2005GL023881.

Schorghofer, N. \& Aharonson, O. 2005. Stability and exchange of subsurface ice on Mars. Journal of Geophysical Research, 110, 10.1029/ 2004JE002350.

Sugden, D.E., Marchant, D.R., Potter JR, N., Souchez, R.A., Denton, G.H., Swisher III, C.C. \& Tison, J.-L. 1995. Preservation of Miocene glacier ice in East Antarctica. Nature, 376, 412-414.

Thompson, D.C., Craig, R.M.F. \& Bromley, A.M. 1971. Climate and surface heat balance in an Antarctic dry valley. New Zealand Journal of Science, 14, 245-251.

VirginIA, R.A. \& WALL, D.H. 1999. How soils structure communities in the Antarctic Dry Valleys. BioScience, 49, 973-983. 